\title{
Contribution to a revision of Hoya (Apocynaceae: Asclepiadoideae) of Papuasia. Part I: ten new species, one new subspecies and one new combination
}

\author{
N. Simonsson Juhonewe ${ }^{1} \&$ M. Rodda ${ }^{2}$ \\ ${ }^{1}$ Research affiliate at National Research Institute of Papua New Guinea \\ Home address: PO Box 1 - 524, Ukarumpa, EHP 444, Papua New Guinea \\ ${ }^{2}$ Herbarium, Singapore Botanic Gardens, National Parks Board, \\ 1 Cluny Road, Singapore 259569 \\ rodda.michele@gmail.com
}

\begin{abstract}
The large majority of Hoya R.Br. species known from Papuasia were described in the first half of the 20th century and most of these are endemic. Along with Borneo and the Philippines the region is a centre of diversity of the genus. Since 2006 herbarium materials have been studied for a revision of Hoya of New Guinea along with field investigations on Papuasian Hoya since 2010. In the present paper we publish ten new species, Hoya brassii P.I.Forst. \& Liddle ex Simonsson \& Rodda, H. carrii P.I.Forst. \& Liddle ex Simonsson \& Rodda, H. edholmiana Simonsson \& Rodda, H. evelinae Simonsson \& Rodda, H. juhoneweana Simonsson \& Rodda, H. krusenstierniana Simonsson \& Rodda, H. koteka Simonsson \& Rodda, H. stenakei Simonsson \& Rodda, H. versteegii Simonsson \& Rodda and H. yvesrocheri Simonsson \& Rodda, one subspecies, H. juhoneweana ssp. lindforsiana Simonsson \& Rodda, and make one new combination, H. urniflora (P.I.Forst.) Simonsson \& Rodda, which is also lectotypified.
\end{abstract}

Keywords. Indonesia, Marsdenieae, Papua New Guinea

\section{Introduction}

Hoya R.Br., with an estimated 350-450 species (Rodda, 2015), is the largest genus in the Apocynaceae. The most species-rich regions for Hoya are in tropical and subtropical South Asia, Southeast Asia and Papuasia. The genus also extends to the Himalayan foothills to the northwest, Okinawa (Japan) to the northeast, Australia to the south and the Fiji Islands to the southeast. The plants are generally epiphytic or hemi-epiphytic climbers or have a pendulous habit, with a few shrubby species (Rodda \& Ercole, 2014; Rodda et al., 2014a).

Recent regional revisions are only available for Peninsular Malaysia (Rintz, 1978), China (Li et al., 1995) and Australia (Forster \& Liddle, 1996). A guidebook to Hoya of Borneo has just been published (Lamb \& Rodda, 2016) but a revision for the island is still in preparation (Rodda, in prep.). Species diversity is highest in the Malesian islands, in particular in the Philippines, Borneo and New Guinea. In both the Philippines and Borneo the number of species known has dramatically increased in 
recent years. Kloppenburg (1991) suggested that the Philippines might have in excess of 30 species, a number that has since climbed to 104 species (Aurigue et al., 2013) with a further 80 new taxa published since 2013 (IPNI, 2016). However, the actual number of species in the Philippines is pending a critical revision. Forster et al. (1998) noted the species diversity of Hoya in Borneo was 'unknown' but recent research has since led to the description of numerous new species in preparation for a comprehensive revision (Rodda \& Nyhuus, 2009; Rodda et al., 2011, 2014a, 2014b, 2015, 2016; Rodda \& Simonsson, 2011a, 2011b; Rodda \& Simonsson Juhonewe 2013a, 2013b; Lamb et al., 2014; Rahayu et al., 2015; Rodda, 2015; Lamb \& Rodda, 2016), and a checklist that includes 71 species and one subspecies (Lamb \& Rodda, 2016).

The island of New Guinea has 74 species according to Forster (1996), mostly described in the first half of last century. Papuasia lies towards the eastern edge of the distribution area of the genus Hoya and includes the Papua and West Papua provinces of Indonesia, Papua New Guinea (PNG), and the Solomon Islands. The largest land mass is the island of New Guinea, the largest tropical island in the world. Major contributions to Hoya of New Guinea were published by Schlechter, almost entirely based on his own collections obtained during expeditions between 1901 and 1909 (Schlechter, 1905, 1908, 1913). Schlechter's collections are limited to German New Guinea, now part of PNG. Moore (1916) described numerous Hoya species from Indonesian New Guinea, based on specimens collected by Boden Kloss. For the Solomon Islands Hoya species were first published by Hemsley $(1891,1892,1894)$.

The most recent contributions to the Hoya of New Guinea were published by Forster \& Liddle (1991, 1992, 1993) and Forster et al. (1995). Forster et al. (1997) described the monotypic genus Madangia P.I.Forst., Liddle \& I.M.Liddle which has since been synonymised into Hoya (Wanntorp \& Forster, 2007).

Despite the large number of species already recorded, the Hoya diversity of PNG is still poorly known. Early exploration was focused mostly in Madang and Morobe Provinces of PNG (Forster, 1996), leaving much of the island unexplored and, consequently, the likelihood of large numbers of new taxa yet to be discovered (Forster 1996; Prance et al., 2000). Indonesian New Guinea is overall much less explored than PNG (Forster, 2006) and only 16 species have so far been recorded from both Indonesian New Guinea and PNG (Forster, 1996, 2006).

The island of New Guinea is dominated by the mountain ranges that run the length of the island. These mountains can exceed $3000 \mathrm{~m}$ and divide the island in a cratonic southern half and accreted terranes to the north (Brown et al., 2006; Heads, 2006). The varied topography, in combination with ever-wet versus monsoonal climate zones (Whitmore, 1984; Van Welzen, 1998), offers a large number and variety of biogeographic zones that support high species richness, as observed for example in orchids (Vollering et al., 2016) and Rhododendron (Brown et al., 2006). Despite the lack of biogeographic data on Hoya, based on our observations the lowland rainforests and lower montane forests appear to harbour the majority of Hoya species, while the montane forests have a high percentage of local endemics. Only a very few species go beyond 2000 m, most notably Hoya krusenstierniana Simonsson \& Rodda (here 
published) that inhabits the cold upper montane forests from $1800 \mathrm{~m}$ up to $2600 \mathrm{~m}$. That is surprisingly high, since Hoya has its upper limit at $2200 \mathrm{~m}$ on both Borneo and Sumatra (Lamb \& Rodda, 2016). Above $2600 \mathrm{~m}$, in the sub-alpine vegetation, no Hoya species have so far been discovered. Along the shoreline, with rough conditions such as saline winds, strong sun exposure and little shade, there are only a few Hoya species capable of growing, although often quite abundantly. These coastal species are widespread all along New Guinea's coastline and its outlying islands, e.g. Hoya anulata Schltr., H. australis R.Br. ex J.Traill, H. globulifera Blume, H. nicholsoniae F.Muell., $H$. inconspicua Hemsl. and H. ischnopus (Warb.) Schltr. The coastal species, being common and easily accessible, are thus the most abundantly represented New Guinean species in herbaria and were also the most frequently encountered species during the first author's expeditions in lowland PNG. As these species are hardy, widespread, and tolerant of weather extremes, they have also been sighted on big trees in cities, in gardens, in secondary forests and even growing up to $1400 \mathrm{~m}$ (except $H$. inconspicua that is limited to the lowlands). In contrast, almost all other Hoya species are confined to primary forests or their margins and are often absent from secondary forests. They are thus vulnerable due to forest clearance for agriculture and timber harvesting. Except for the widespread coastal species, there is almost no overlap between species in the highlands and lowlands. There are two common montane species that are capable of growing outside of primary forests, recolonising secondary forests and even growing on trees in villages and gardens; these are $H$. solaniflora Schltr. and $H$. subglabra Schltr. Both species are frequently seen in bright locations between 1500 and $1800 \mathrm{~m}$ all over the Highlands in PNG.

New Guinea has several species complexes of similar taxa that may turn out to be fewer variable species once more collections are gathered from the more remote areas of the island. These complexes include the Hoya ischnopus complex (which includes $H$. dimorpha F.M.Bailey, $H$. dischorensis Schltr., $H$. flavescens Schltr., $H$. kenejiana Schltr. and $H$. montana Schltr.) and the $H$. globulifera complex (including $H$. lamingtoniae F.M.Bailey and $H$. rubida Schltr.). A third more challenging group includes all members of Hoya section Eriostemma Schltr. which are common and widespread throughout the Malesian region and Papuasia. Species delimitation within this section is particularly problematic.

New Guinea's Hoya species harbour several extremes of morphology for the genus, including the smallest leaved species such as Hoya microphylla Schltr., $H$. pulchella Schltr., $H$. oxycoccoides S.Moore and $H$. krusenstierniana. The largest flowers are recorded from New Guinea, Hoya gigas Schltr. and H. lauterbachii K.Schum., and the almost as large, newly discovered, H. stenakei Simonsson \& Rodda.

The majority of New Guinea's species of Hoya have large (occasionally $>3$ $\mathrm{cm}$ ), campanulate or urceolate corollas. Even species forming small plants such as Hoya pulchella, $H$. patella Schltr. and $H$. juhoneweana ssp. lindforsiana Simonsson \& Rodda have large flowers. This is not observed in Borneo or Philippine Hoya, where the majority of species have reflexed (Borneo) or revolute (Philippines) corollas and only a few taxa have campanulate corollas. 


\section{The current project}

In the current project we set out to study all herbarium specimens from Papuasia, several of which were already known to represent new species (Forster \& Liddle, 1992), and to conduct extensive field surveys in PNG to obtain new collections. Herbarium materials were studied at B, BM, BO, CGE, G, K, L, LAE, OXF, P, SAN, SAR, SING and Z. Loans from A and US were studied at SING. Forster \& Liddle (1992) stated that a comprehensive revision of the genus in Papuasia would require extensive fieldwork and cultivation of field-collected material that would take many years. Cultivation of field-collected materials for the description of new species and photo documentation has been successfully adopted by Rintz (1978) and Lamb et al. (2014) for Peninsular Malaysia and Sabah Hoya respectively. Our observations in the field confirmed the need to cultivate sterile field-collected specimens as only approximately one out of every 300 Hoya individuals observed were in flower during the fieldwork. A revision based only on specimens collected in flower during fieldwork would result in the omission of over $99 \%$ of the total plants sighted in the field. Therefore, the first author moved to PNG in 2010 to conduct extensive field work in all provinces and to cultivate selected collections at two different altitudes to obtain flowering material. The plants were grown in Lae, Morobe Province, for low altitude species, and in Kainantu, Eastern Highlands Province, at $1500 \mathrm{~m}$ altitude, for high altitude species.

By December 2015, 55 field expeditions in 11 provinces (Fig. 1) had been carried out and data gathered on locality, habitat, population count and size, presence of ants, size of host tree and forest type for more than 4000 Hoya individuals. A selected 1500 specimens have been brought into cultivation (Fig. 2). Once they flower they are photographed and made into herbarium specimens. The materials gathered will be used for conservation, taxonomic and molecular studies.

The purpose of the present paper is to describe 10 species and one subspecies that have been identified as new among the herbarium specimens, new field collections and cultivated collections that have already flowered. We also move Marsdenia urniflora P.I.Forst into Hoya. All specimens that could be georeferenced have been plotted in Fig. 1.

\section{Taxonomy}

Hoya brassii P.I.Forst. \& Liddle ex Simonsson \& Rodda, sp. nov.

Similar to Hoya globulifera Blume in leaf shape (linear-lanceolate) but distinguished by its much shorter petioles (1-2 $\mathrm{mm}$ in $\mathrm{H}$. brassi, $>4 \mathrm{~mm}$ in $\mathrm{H}$. globulifera), much shorter peduncles $($ c. $1 \mathrm{~mm}$ vs. $>1 \mathrm{~cm})$ and inflorescences with fewer flowers $(1-10$ vs. 10-30 flowers). - TYPE: Papua New Guinea, Western Province, Palmer River, 2 miles below junction with Black River, 100 m., June 1936. Brass, L.J. 6883 (holotype A [A00353955], BM [BM001014248], BRI n.v.). (Fig. 3, 4) 


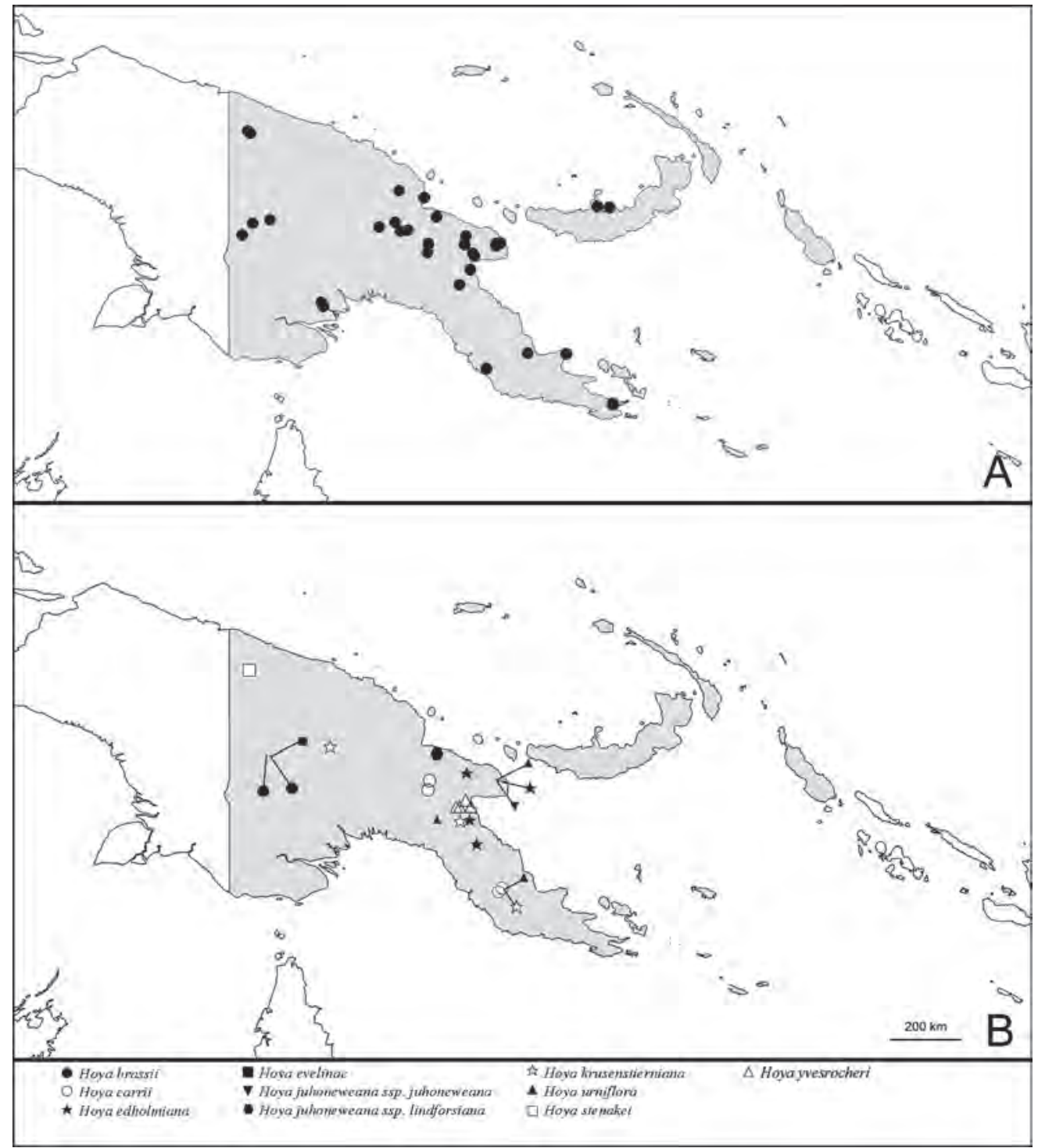

Fig. 1. Map of Papua New Guinea (shaded in grey) with A. Localities visited by the first author between 2011 and 2015. B. Collection localities of the new species published in the present paper, excluding Hoya versteegii and Hoya koteka. Map constructed using SimpleMappr (www.simplemappr.net). 


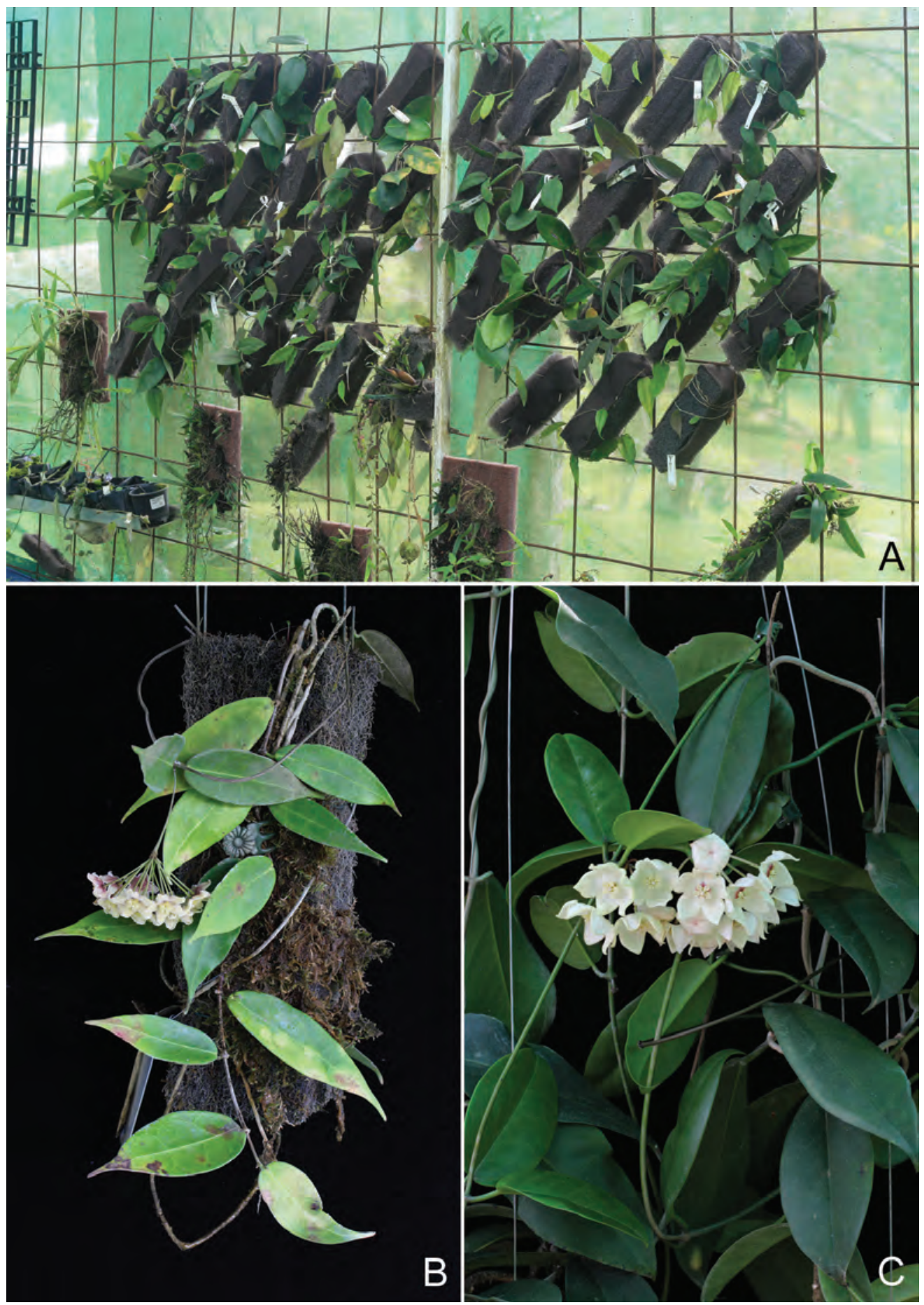

Fig. 2. A. Recently wild-collected plants in cultivation at Ukarumpa, PNG. B. Hoya edholmiana in bloom in cultivation (live collection no. NS11-232). C. Two of the many clones of Hoya calycina complex. (Photos: N. Simonsson Juhonewe) 
Epiphytic climber with white latex in all vegetative parts. Stems cylindrical, stiff, 2-3 m long, 1.5-3 $\mathrm{mm}$ in diameter, green to greyish brown, glabrous or sparsely pubescent; older stems leafless, up to $5 \mathrm{~mm}$ in diameter, greyish brown, glabrous with peeling bark; internodes (1-)3-15 cm long. Adventitious roots sparsely produced along the stem. Leaves petiolate; petiole terete, $1-2 \times$ c. $1.5 \mathrm{~mm}$ in diameter, greyish green, glabrous; lamina linear-lanceolate, 1-2 mm thick, fleshy, 5-11 × 1-2.5 cm, bright to dark green on adaxial surface, light green on abaxial surface, glabrous, apex acute to acuminate, base round to attenuate, basal colleters 2, ovoid, 4-5 × 1.5-2 mm; venation pinnate, midrib depressed on adaxial surface, secondary veins $2-5$ each side, barely evident in living material, more visible in dry material, diverging at $20-45^{\circ}$. Inflorescences one per node, extra-axillary, positively geotropic, convex, consisting of 1-10 flowers; peduncle terete, c. $1 \times 2 \mathrm{~mm}$, older peduncles developing a rachis from previous flowerings, new peduncles glabrous or sparsely pubescent, older peduncles glabrous; pedicels terete, $10-15 \times$ c. $1 \mathrm{~mm}$ in diameter, light green-yellow, often with red spots, papillate to glabrous, warty. Flower buds apically flattened, cream white to pale yellow with reddish spots. Calyx c. $3 \mathrm{~mm}$ in diameter, lobes deltoid, c. $1 \times 1 \mathrm{~mm}$, apex broadly acute to obtuse, margin sparsely ciliate; basal colleters one in each calyx lobe sinus, deltoid. Corolla rotate, concave, $1-1.5 \mathrm{~cm}$ in diameter (c. $1.5 \mathrm{~cm}$ when flattened), cream white to pale yellow, often with red spots on abaxial surface, also visible on the adaxial surface as pink spots; tube 3-3.5 mm long; lobes ovate, $4-5 \times$ 5-6 mm, adaxially thinly pubescent, denser at base of the corona, abaxially glabrous, apex acute, revolute. Corona staminal 1.5-1.7 mm high, c. $3.5 \mathrm{~mm}$ in diameter, fleshy, cream white to pale yellow with maroon centre; lobes obovate, c. 1.5 × 1-1.2 mm, inner processes slightly erect, apices acute, outer processes usually slightly erect to same level as inner processes, apex obtuse when observed from above, deeply grooved between inner and outer processes, not basally fused with the filament tube, with basal revolute margins. Style-head convex to same level as inner corona processes, hidden by anther appendages. Pollinia oblong slightly tapering at the base, with sterile edge, c. $450 \times 200 \mu \mathrm{m}$, corpusculum squarish, c. $170 \times 150 \mu \mathrm{m}$, caudicles attached at the sides of corpusculum, 70-100 $\mu \mathrm{m}$ long. Ovary broadly conical, glabrous. Fruits and seeds not observed.

Distribution. Recorded only from one single locality at the confluence of Palmer River and Black River in the northwestern corner of PNG Western Province at 100-150 m.

Etymology. Named after Leonard John Brass (1900-1971), an Australian botanist who collected the type specimen in 1936 on the Fly River Expedition of the American Museum of National History (the second Archbold New Guinea Expedition).

Habitat and ecology. At the type locality Hoya brassii is commonly found at the top of mature primary forest trees, in bright light conditions. It was absent in the understorey where the new taxon Hoya evelinae Simonsson \& Rodda was instead abundant. 


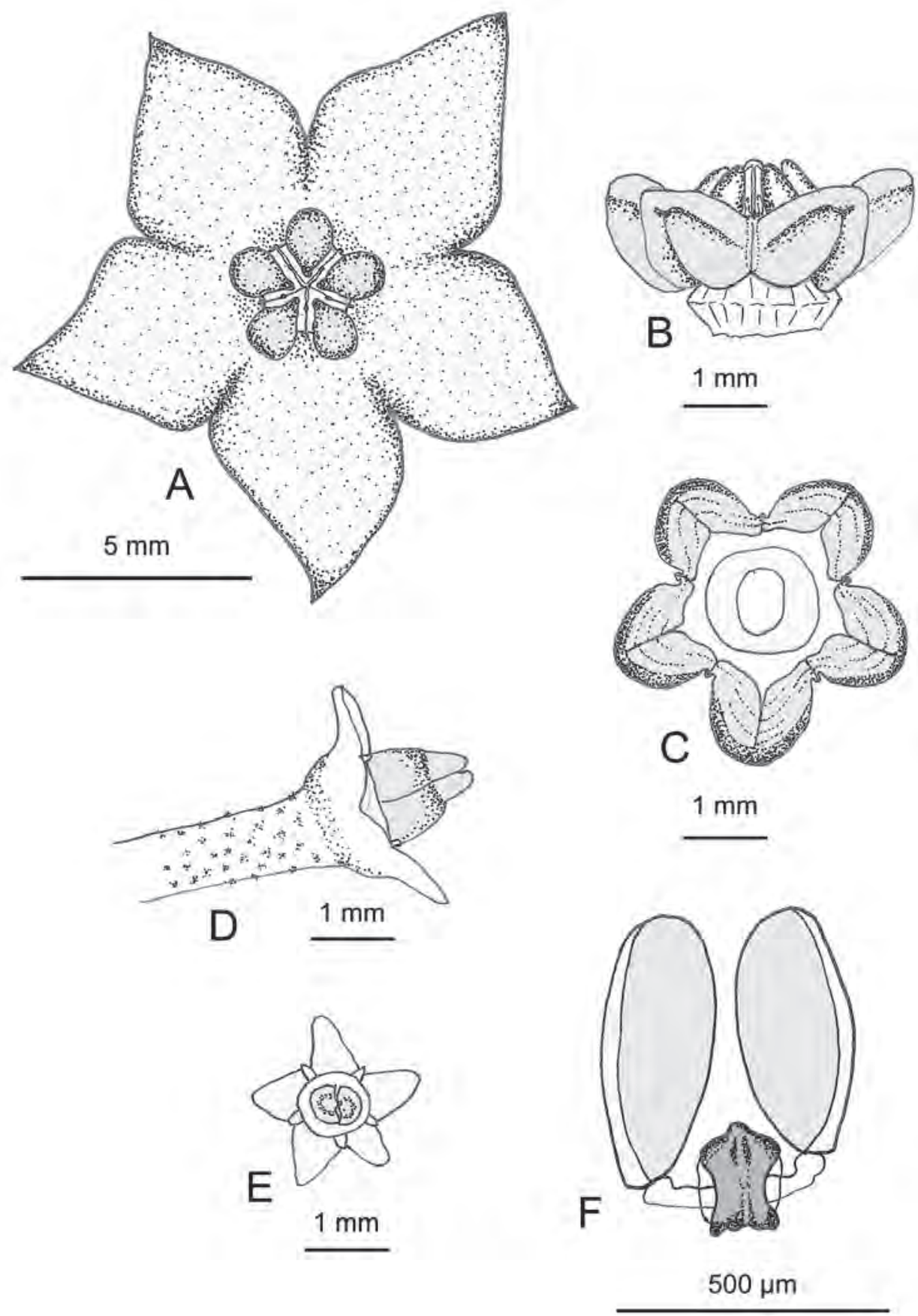

Fig. 3. Hoya brassii Simonsson \& Rodda. A. Corolla, top view. B. Corona, side view. C. Corona, from underneath. D, E. Calyx. F. Pollinarium. All from Simonsson Juhonewe, N. \& Juhonewe, F. NS0034L. (Drawing: M. Rodda) 


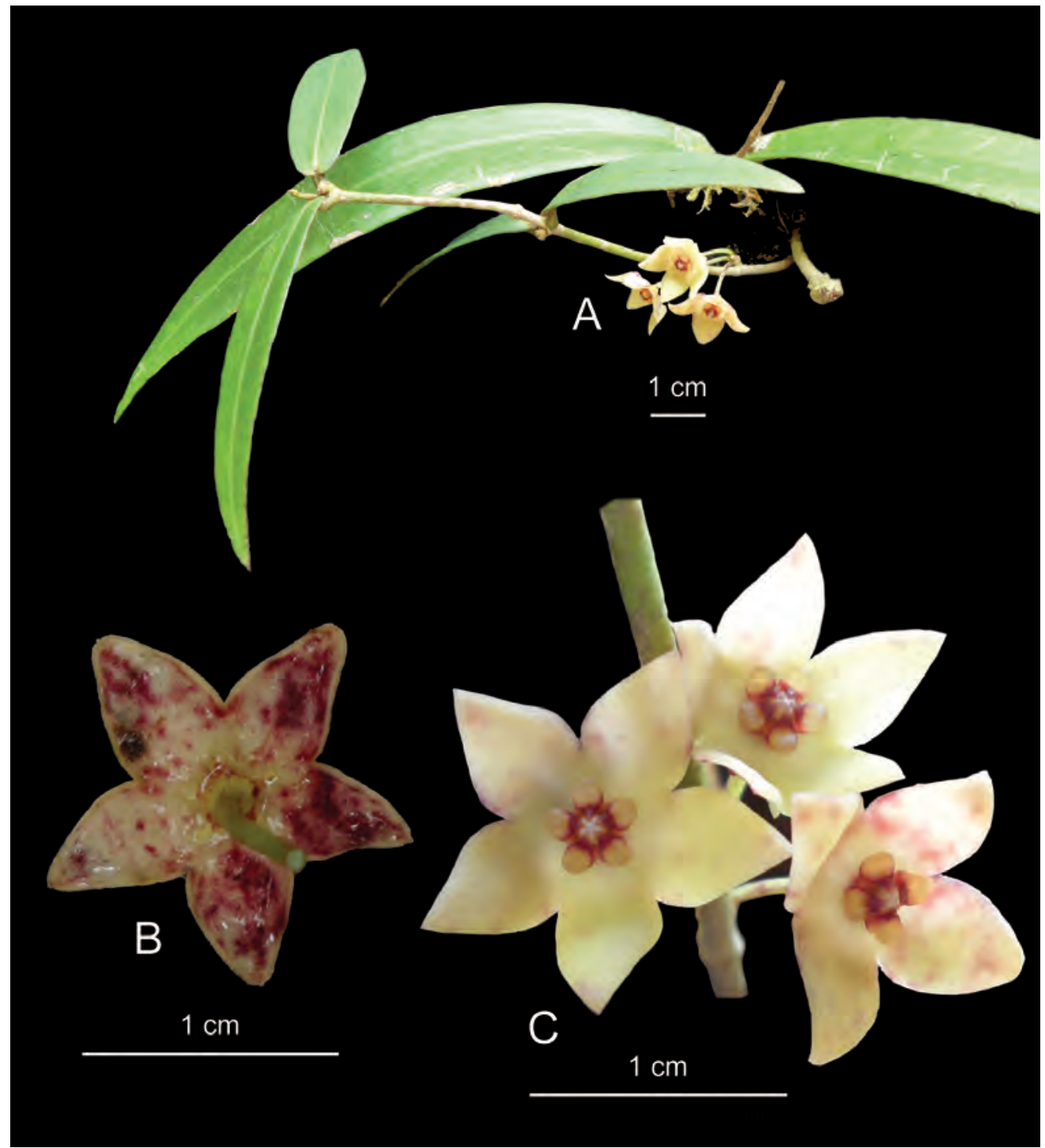

Fig. 4. Hoya brassii Simonsson \& Rodda. A. Flowering branch. B. Inflorescence from above. C. Corolla and calyx from underneath. All from Simonsson Juhonewe, N. \& Juhonewe, F. NS0042L. (Photos: N. Simonsson Juhonewe)

Provisional IUCN conservation assessment. Critically Endangered CR B1a,b(iii) (IUCN, 2016). The species appears to be common at the type locality but it may be locally endemic as it has not been recorded from elsewhere, either from herbarium specimens or during the first author's fieldwork. Much of PNG Western Province's lowland rainforest has been, or is being, logged (Shearman et al., 2009) and the type locality is not inside a protected area and may be lost in the near future. 
Additional specimens examined. PAPUA NEW GUINEA: Western Province: Palmer River, 2 miles below junction Black River, slender climber common in substage forest of ridges, 100 m, pale yellow flowers mottled with brown on outer side, Jun 1936, Brass, L.J. 6976 (A n.v., BM, BRI n.v., LAE [Sheet 72124]); Palmer River, 2 miles below junction Black River, $100 \mathrm{~m}$, small climber in ridge forest, Jun 1936, Brass, L.J. 7021 (BM, BRI n.v.); Palmer River, 2 miles below junction with Black River, 100 m, slender climber in ridge forests, Jun 1936, Brass, L.J. 7072 (A); cultivated plant grown on from Black River, near Dahamo, living accession NS11100, vouchered at Ukarumpa on 27 May 2012 as Simonsson Juhonewe, N. \& Juhonewe, F. NS0034L (LAE); cultivated plant grown on from Black River, near Dahamo, living accession NS11-129, vouchered in Ukarumpa on 22 Jun 2012 as Simonsson Juhonewe, N. \& Juhonewe, F. NS0042L (LAE).

Notes. A small-flowered species from the lowlands of PNG Western Province that may be confused with the widespread and common Hoya globulifera Blume because both species have linear-lanceolate leaves with pinnate venation and secondary veins held at an acute angle. It is easily distinguished from Hoya globulifera by its very short petioles that are only 1-2 $\mathrm{mm}$ long, by the peduncles that are c. $1 \mathrm{~mm}$ long and the inflorescences that have 1-10 cream white to pale yellow flowers, often spotted in (brownish) red with short hairs on the inside of the corolla. Hoya globulifera instead has petioles $>4 \mathrm{~mm}$ long, peduncles $>1 \mathrm{~cm}$ long, and inflorescences bearing 10-30 flowers with a colour range from dull yellow-purple to rich maroon with corollas covered by long hairs on the inside. The taxon was long recognised as a new species by Paul Forster and David Liddle and the type specimen Brass, L.J. 6883 was already labelled as such by them. P.I.Forst. \& Liddle are therefore recognised as "ex" authors for Hoya brassii.

Hoya carrii P.I.Forst. \& Liddle ex Simonsson \& Rodda sp. nov.

Similar to Hoya solaniflora Schltr. in the rotate corolla, but distinguished from it by the plant being a vigorous climber with thick leaves (up to $3 \mathrm{~mm}$ thick) and with a corolla $3 \mathrm{~cm}$ in diameter when flattened, whereas $H$. solaniflora is a more slender vine, with thinner laminae (0.5-1.5 mm thick), and flowers c. $2 \mathrm{~cm}$ in diameter when flattened. TYPE: Papua New Guinea, Oro Province, Isuarava, epiphytic climber, forest c. 4500 ft. [c. 1370 m] , 3 March 1936, Carr, C.E. 15904 (holotype SING [SING0227204]; isotype B [B100277188], BM [BM001014247], BRI n.v., K, NY [NY00074132], SING [SING0227204], LAE). (Fig. 5-7)

Epiphytic climber, vigorous with white latex in all vegetative parts. Stems cylindrical, 2-4 $\mathrm{m}$ long, 1.5-3 $\mathrm{mm}$ in diam., greyish green, glabrous or rarely sparsely pubescent on younger stems; older stems leafless, up to $5 \mathrm{~mm}$ in diameter, greyish brown, glabrous with peeling bark; internodes 1.5-15(-20) cm long. Adventitious roots sparsely produced along the stems. Leaves petiolate; petiole terete, 6-12 $\times 1-1.5 \mathrm{~mm}$ in diam., green when young, greyish brown when old, glabrous; Iamina narrowly elliptic-acuminate, very thick and fleshy, often up to $3 \mathrm{~mm}$ thick, (4-)7-13 $\times(1.5-) 2-4 \mathrm{~cm}$, dark green on adaxial surface, light green on abaxial surface, glabrous, apex acuminate to acute, base 
rounded, sometimes slightly revolute, more evident on dry material, immature leaves often reddish-maroon, with 1 basal colleter, globose, 3-4 × 3-4 mm; venation pinnate, midrib depressed on adaxial surface, secondary veins $2-5$ each side, light green and sometimes slightly elevated, anastomosing near the leaf margin, branching from the midrib at 40-90 . Inflorescences one per node, extra-axillary, positively geotropic, convex, consisting of (2-)6-12 flowers; peduncle terete, 1-6 cm × 1-2 mm, older peduncles forming a rachis from previous flowerings, glabrous or sparsely pubescent; pedicels terete, $2-4 \mathrm{~cm} \times$ c. $0.6 \mathrm{~mm}$ in diameter, pedicel reddish green. Flower buds apically flattened, cream-white, often red near the calyx. Calyx c. $6 \mathrm{~mm}$ in diameter, lobes elliptic-deltoid, c. $1.5 \times 1.5-2 \mathrm{~mm}$, apex rounded or acute, glabrous to sparsely pubescent; basal colleters one in each sepal sinus, round to deltoid. Corolla rotate, concave, c. $2.5 \mathrm{~cm}$ in diameter (c. $3 \mathrm{~cm}$ when flattened), pure white to cream-white with varying degree of crimson under the corona, often also visible on the outer surface; tube 5-6 mm long, lobes ovate, $0.7-1 \times 0.7-1 \mathrm{~cm}$, thickly pubescent inside, glabrous outside, margin recurved, apex acuminate, recurved. Corona staminal, c. $3 \mathrm{~mm}$ high, 8-10 $\mathrm{mm}$ in diameter, fleshy, creamy yellow(-greenish); corona lobes 5, rhomboid when seen from above with ovate top and a central deep groove, 4-5 × c. $3 \mathrm{~mm}$, inner processes flat to slightly erect, apex acuminate, outer processes flat to slightly erect, usually at same level as inner processes, not basally fused with the filament tube, with basal revolute margins. Style-head convex, hidden by anther appendages at same level or barely exceeding the apices of inner coronal processes. Pollinia oblong with sterile edge, c. $920 \times 370 \mu \mathrm{m}$, corpusculum rhomboid, c. $500 \times 300 \mu \mathrm{m}$, caudicles attached at the sides of corpusculum, c. 120-150 $\mu \mathrm{m}$ long. Ovary conical, often with a mammillate tip, c. $2 \mathrm{~mm}$ long; each carpel c. $1 \mathrm{~mm}$ wide at base, glabrous. Fruits and seeds not observed.

Distribution. Carr collected Hoya carrii (Carr 13084, Carr 13500, Carr 14768, Carr 15366) at two sites c. $15 \mathrm{~km}$ apart on the Kokoda Track along the border of Central and Oro Provinces, at c. $1370 \mathrm{~m}$ altitude (4500 ft.). Later, during the first author's fieldwork, two populations were found $25 \mathrm{~km}$ apart, c. $340 \mathrm{~km}$ northwest of the type locality (Simonsson Juhonewe \& Juhonewe NS0066H, Simonsson Juhonewe \& Juhonewe NS0078H, Simonsson Juhonewe \& Juhonewe NS0079H, Simonsson Juhonewe \& Juhonewe NS0097L) in Obura-Wonenara, Eastern Highlands Province, at c. $1800 \mathrm{~m}$ altitude in mossy forests on ridges, flowering in January and November. The species seems to be uncommon, but where it is found it is locally abundant.

Etymology. Named after C. E. Carr (1892-1936), who first collected the taxon in 1935, and again in 1936, on a collecting expedition supported by the British Museum, London, which started in 1934. He died of malaria in June 1936, just a few months after discovering the second locality of Hoya carrii.

Habitat and ecology. Found on ridges at 1400-1800 m, on mature trees or mossy undergrowth in primary forests. Not observed in nearby re-growth. In the wild and in cultivation in PNG it usually flowers during November - January. 


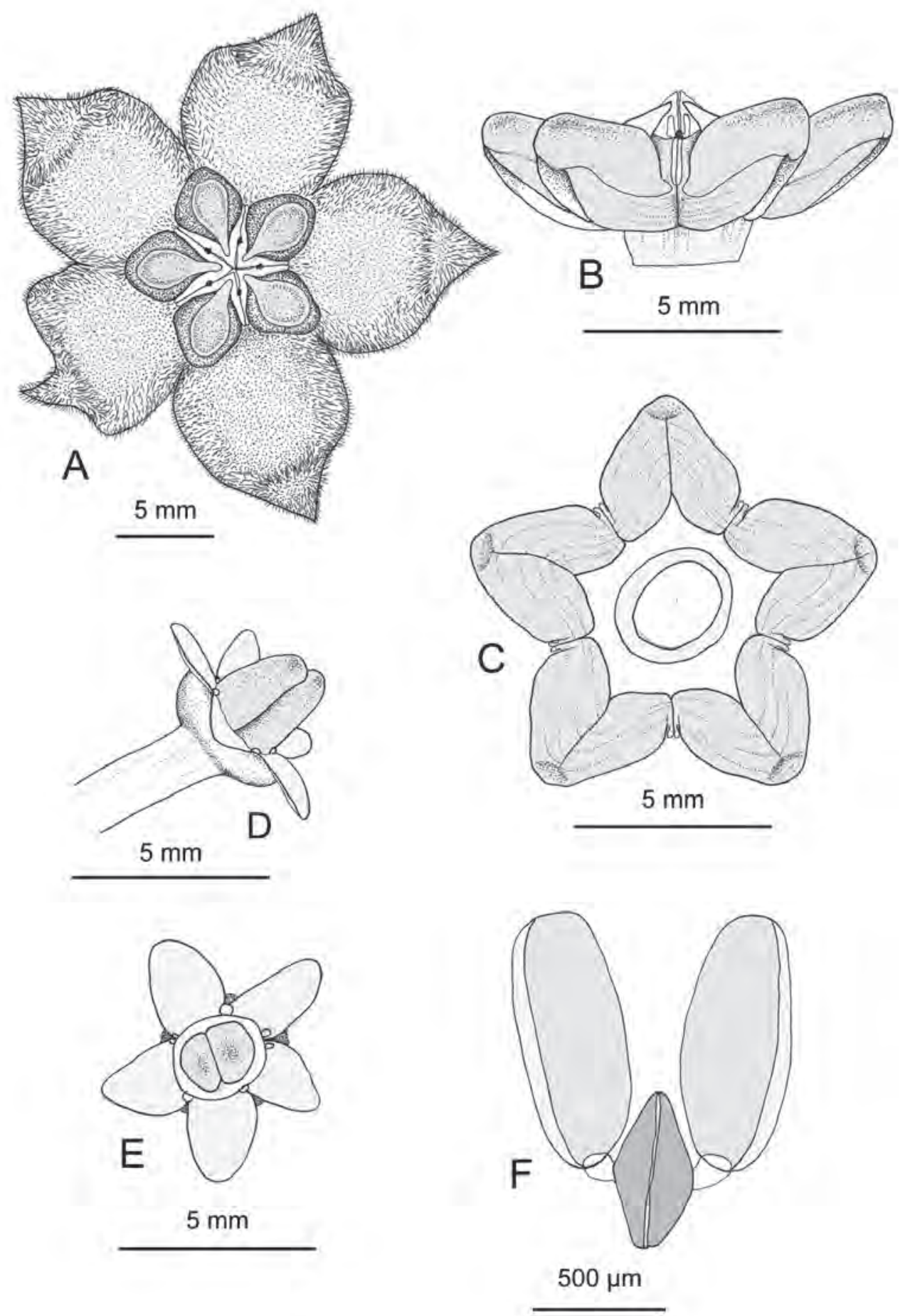

Fig. 5. Hoya carrii Simonsson \& Rodda. A. Corolla, top view. B. Corona, side view. C. Corona, from underneath. D, E. Calyx. F. Pollinarium. All from Simonsson Juhonewe \& Juhonewe NS0066H. (Drawing: M. Rodda) 

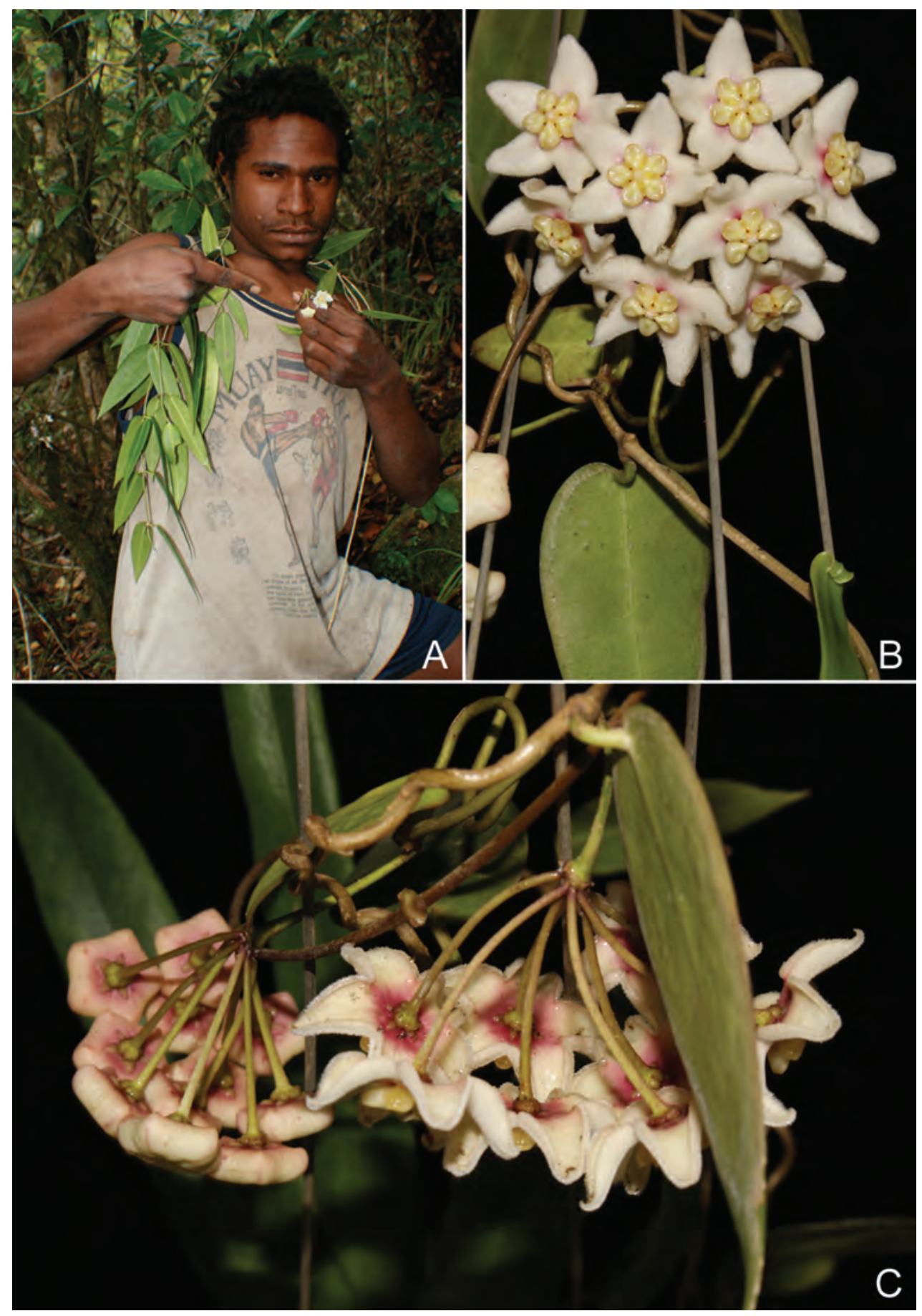

Fig. 6. Hoya carrii Simonsson \& Rodda. A. Proudly displayed as an adornment by a local collector B. In cultivation at Ukarumpa, inflorescence from beneath (living plant NS13-064). C. In cultivation at Ukarumpa, inflorescence from above (living plant NS13-064). (Photos: N. Simonsson Juhonewe) 


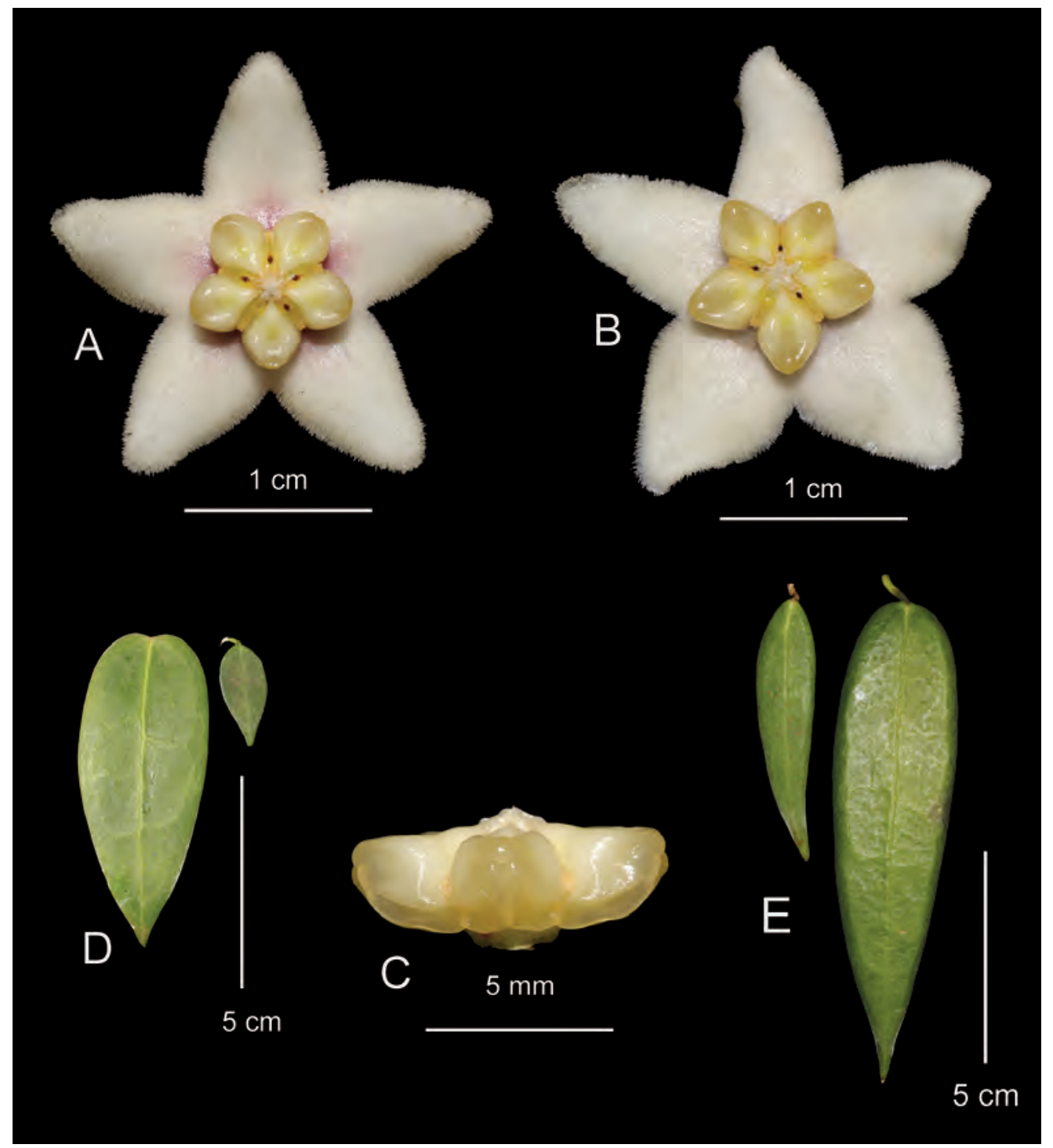

Fig. 7. Hoya carrii Simonsson \& Rodda. A, B. Corolla, top view. C. Corona, side view. D, E. lamina, from above. (A, D from live plant NS13-064, C from NS13-092, B, E from NS13065). (Photos: N. Simonsson Juhonewe)

Provisional IUCN conservation assessment. Critically Endangered CR B2a,b(iii) (IUCN, 2016). The type locality is along the famous Kokoda Track that is still covered by thick forest, but further development along the track with expanding population may reduce the forest cover greatly. The forest in the two recently recorded localities is under high pressure from expanding population because of slash-and-burn agriculture that later turns the landscape into eroded abandoned grassy fields. Hoya carrii has not been recorded elsewhere, neither in herbaria nor during the first author's fieldwork. 
Additional specimens examined. PAPUA NEW GUINEA: Central Province: Boridi, 10 Oct 1935, Carr, C.E. 13084 (BM, SING [SING0121812]); Boridi, 2 Nov 1935, Carr, C.E. 14768 (BM, SING [SING0121815]); Boridi, 25 Nov 1935, Carr, C.E. 13500 (BM, SING [SING0121814]); Oro Province: Isuarava, 3 Feb 1936, Carr, C.E. 15366 (BM, SING [SING0121813, SING0121816, SING0121817]); Eastern Highlands Province: OburaWonenara, Baira, 25 Jan 2013, Simonsson Juhonewe, N \& Juhonewe, F. NS0066H (LAE, SING) (living accession NS13-065); Obura-Wonenara, Kamanangkera, 27 Nov 2013, Simonsson Juhonewe, N., Juhonewe, F. \& Apa Apako NS0079H (LAE) (living accession NS13092); Obura-Wonenara, Kamanangkera, 27 Nov 2013, Simonsson Juhonewe, N., Juhonewe, F. \& Apa Apako NS0078H (LAE) (living accession NS13-093); cultivated plant grown on from Obura-Wonenara, Baira, living accession NS13-064, vouchered at Ukarumpa on 14 Jan 2016 as Simonsson Juhonewe, $N$ \& Juhonewe, F. NS0097L (LAE).

Notes. A montane species not easily confused vegetatively with any other Hoya spp. due to its unusual thick leaves. Amongst other known New Guinean species it most resembles Hoya solaniflora but the stems are more vigorous and robust, the lamina is larger and very thick (often $1.5-3 \mathrm{~mm}$ ) and usually breaks easily if bent, and the flowers are c. $3 \mathrm{~cm}$ in diameter when flattened, whereas $H$. solaniflora is a more slender vine, having laminae $0.5-1.5 \mathrm{~mm}$ thick, and the flowers are c. $2 \mathrm{~cm}$ in diameter when flattened.

The taxon was long recognised as a new species by Paul Forster and David Liddle and the type specimen Carr, C.E. 15904 was already labelled as such by them.

Hoya edholmiana Simonsson \& Rodda, sp. nov.

Similar to the species in the Hoya ischnopus (Warb.) Schltr. species complex (which includes $H$. dimorpha F.M.Bailey, $H$. dischorensis Schltr., H. flavescens Schltr., $H$. kenejiana Schltr. and H. montana Schltr.) in having numerous flowers bearing yellow densely pubescent rotate corollas on slender peduncles, but easily distinguished by the conspicuous bright, raised venation which is lacking in the Hoya ischnopus complex and the corollas being slightly campanulate with grooves under each corona lobe and 1.5 to 2 times the size of the corolla in the Hoya ischnopus complex (measured flat). - TYPE: Papua New Guinea, Morobe Province, Skindiwai, Kuper Range, $21 \mathrm{~km}$ E of Wau, 7¹9'S $146^{\circ} 55^{\prime} \mathrm{E}, 1600$ m, Nothofagus forest, 24 November 1981, Kairo, A. 405 (holotype LAE). (Fig. 8, 9)

Slender liana with white latex in all vegetative parts. Stems cylindrical, 1.5-3 $\mathrm{mm}$ in diameter, greyish green to dark purple, glabrous; older stems often leafless, lignified, up to $5 \mathrm{~mm}$ in diameter, grey-brown, with peeling bark; internodes $3-20 \mathrm{~cm}$ long. Adventitious roots numerous along the stem. Leaves petiolate; petiole terete, 1.5-2 $\times$ c. $1.2 \mathrm{~mm}$ in diameter, greyish green, glabrous; lamina ovate-elliptic, thin, coriaceous, 5-12 $\times 2-5 \mathrm{~cm}$, dark green to purplish on adaxial surface, light green on abaxial surface, glabrous, apex cuspidate to caudate, base round to acuminate, margin entire, often undulate, slightly revolute; venation pinnate, midrib depressed on adaxial surface, secondary veins 4-6 each side, reticulate or inconspicuous, raised adaxially, much lighter in colour when young, anastomosing near the leaf margin, branching 
from the midrib at $50-80^{\circ}$; basal colleters two, light brown. Inflorescence one per node, extra-axillary, positively geotropic, pseudo-umbelliform, convex, consisting of 7-20 flowers; peduncle persistent, terete, slender, 4-15 $\mathrm{cm} \times 1-1.5 \mathrm{~mm}$, glabrous, older peduncles forming a rachis from previous flowerings; pedicels terete, $2-4 \mathrm{~cm}$ $\times$ c. $1 \mathrm{~mm}$ in diameter, light green to purplish red, glabrous. Flower buds cream coloured, flushed pink on parts exposed to the sun. Flowers lasting about one week in cultivation, with a weak scent during the day, more intense at night. Calyx 4-10 mm in diameter, calyx lobes triangular to lanceolate, $1.5-5 \times$ c. $1.5 \mathrm{~mm}$, glabrous, apex rounded to acute, margin glabrous or ciliate. Corolla spreading, 16-22 $\mathrm{mm}$ in diameter (19-25 mm when flattened), cream to pale yellow, flushed pink on the outer surface in specimens growing in bright light; tube 5-7 mm, lobes triangular, slightly fleshy, 6-9 × 5-7 mm, inside thickly and densely covered with $0.5-1 \mathrm{~mm}$ long hairs, outside glabrous, margins recurved, apex acute, recurved. Corona staminal, 2.5-3.5 mm high, 7-9 mm in diameter, fleshy, yellow, somewhat translucent; lobes ovate-elliptic, 3-4.5 $\times 2-2.5 \mathrm{~mm}$, inner processes cuspidate, slightly erect, not meeting (or just barely) in the centre, outer processes apex rounded to obtuse (acute), slightly erect, c. $1 \mathrm{~mm}$ higher than inner processes, carinate above, with basal revolute margins. Style-head convex, hidden by anther appendages. Pollinia oblong, c. $500 \times 200 \mu \mathrm{m}$, with sterile edge, corpusculum ovate 200-250 × 100-120 $\mu \mathrm{m}$, caudicles attached in the middle of corpusculum, c. $70 \times 30 \mu \mathrm{m}$. Ovary broadly conical c. $2 \mathrm{~mm}$ long; each carpel c. $1 \mathrm{~mm}$ wide at the base, light green-yellow, glabrous. Fruits cylindric and tapering, c. $20 \times 1$ $\mathrm{cm}$ (unripe), dark green becoming red-pigmented in sunlight, seeds not seen mature.

Distribution. The species is recorded from the Kuper Range (holotype Kairo 405) and from three additional collections by the first author in Morobe Province (Fig. 1).

Etymology. Named after the siblings Charlize, Diesel and Evelize Edholm of Sweden, supporters of the first author's work in PNG.

Habitat and ecology. Hoya edholmiana was rather abundant at the three localities where it was observed by the first author. It was recorded only at altitudes between c. 1450 and $1850 \mathrm{~m}$. It was absent both further down and further up the mountain during the extensive expeditions, even on the same slope. It is usually an epiphyte but on shaded or partially exposed ridges was also found growing as a lithophyte on mossy rocks, entangled amongst other plants. Where it occurs, it is common in the primary forests and can occasionally be found in adjacent mature secondary forests. It thrives on younger trees along disturbed paths but is absent in the surrounding sunexposed and drier subsistence gardens, where instead H. magnifica P.I.Forst. \& Liddle, H. subglabra Schltr. and Hoya sp. sect. Eriostemma were recorded. The specimens brought into cultivation flower abundantly throughout the year.

Provisional IUCN conservation assessment. Least Concern (IUCN, 2016). It appears to be rather common and somewhat capable of re-colonising moist secondary forests. It has only been recorded in Morobe Province. 

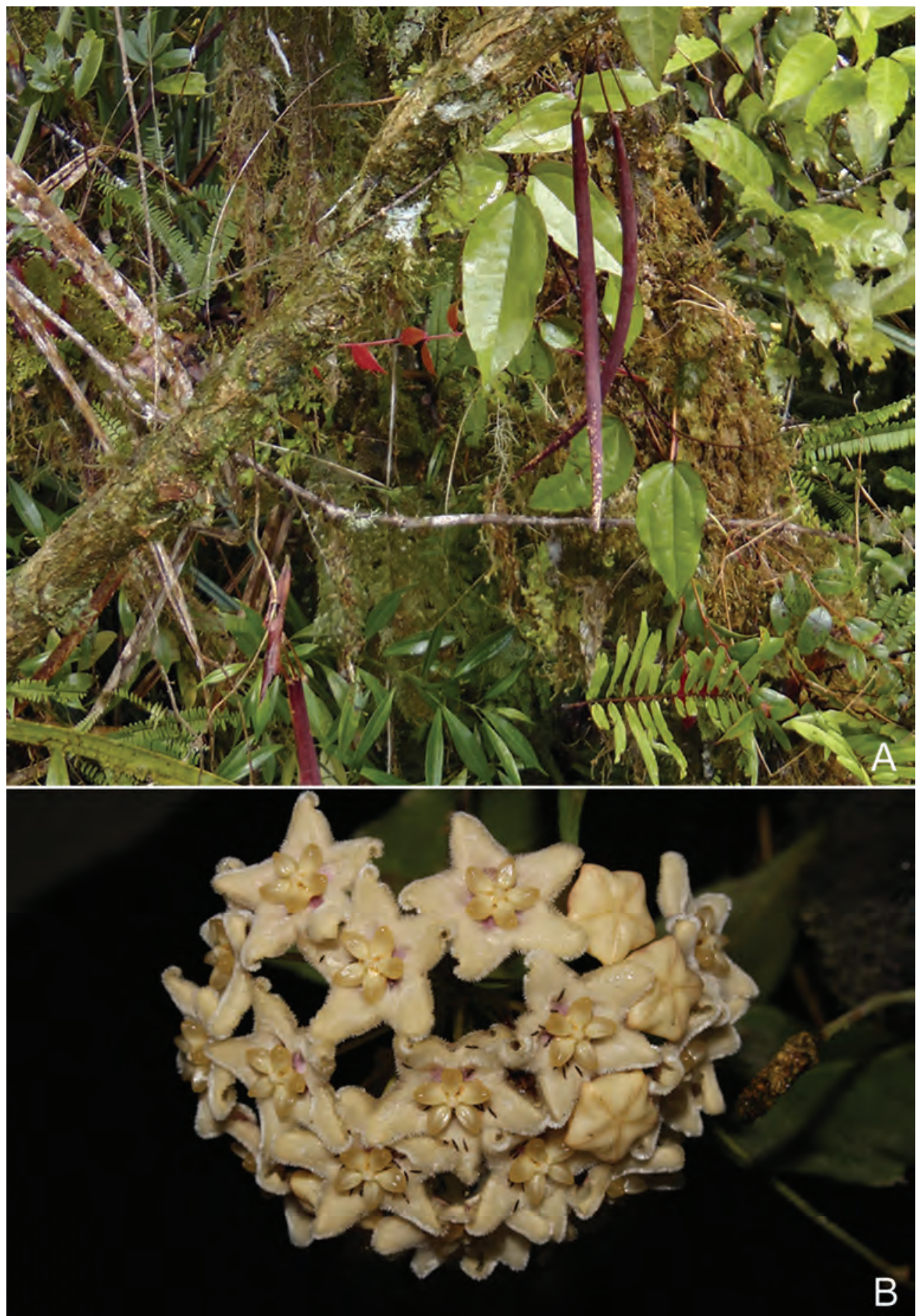

Fig. 8. Hoya edholmiana Simonsson \& Rodda. A. Fruiting plant in situ in Finisterre Range, Yawan. B. Whole inflorescence. A from live plant NS11-210; B from Simonsson Juhonewe, N., \& Juhonewe, F. NS0009H. (Photos: N. Simonsson Juhonewe) 


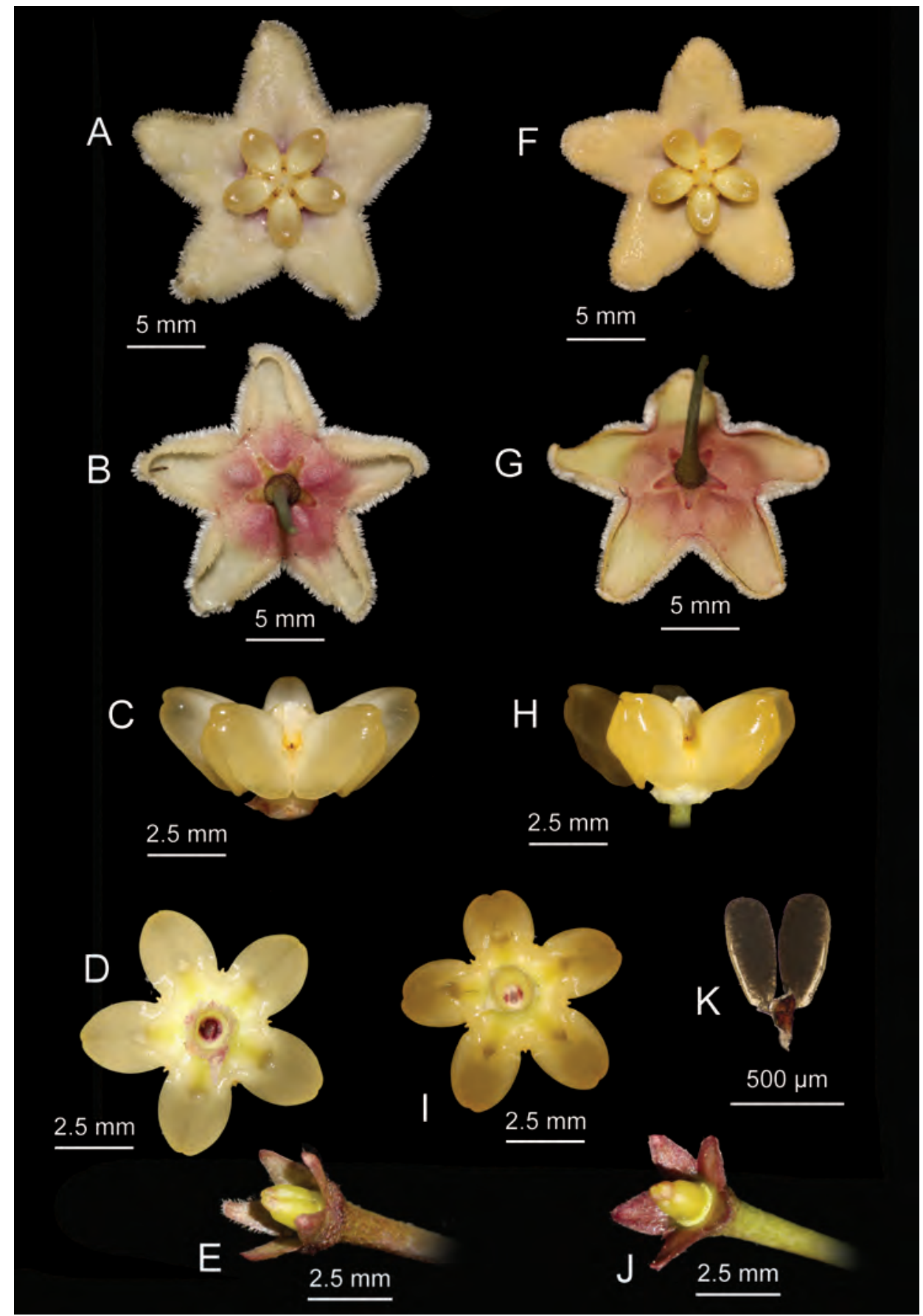

Fig. 9. Hoya edholmiana Simonsson \& Rodda. A, F. Corolla, top view. B, G. Corolla, from underneath. C, H. Corona, side view. D, I. Corona, from underneath. E, J. Calyx. K. Pollinarium. A-E from Simonsson Juhonewe, N., \& Juhonewe, F. NS0008H; F-J from NS11-232; K from Simonsson Juhonewe N. \& Juhonewe, F. NS0039L. (Photos A-J: F. Juhonewe; K: M. Rodda). 
Additional specimens examined. PAPUA NEW GUINEA: Morobe Province: Finisterre Range, Yawan, 1713 m, 1 Apr 2011, Simonsson Juhonewe, N., \& Juhonewe, F. NS0008H (LAE), (living accession NS11-212); Finisterre Range, Yawan, 1740 m, 1 Apr 2011, Simonsson Juhonewe, N., \& Juhonewe, F. NS0009H (LAE) (living accession NS11-218); Finisterre Range, Yawan, 1800 m, 1 Apr 2011, Simonsson Juhonewe, N., \& Juhonewe, F. NS0010H (LAE) (living accession NS11-226); cultivated plant grown on from Finisterre Range, Yawan, 1713 m, living accession NS11-212, vouchered at Ukarumpa on 21 Jun 2012 as Simonsson Juhonewe, N. \& Juhonewe F. NS0038L (LAE, SING); cultivated plant grown on from Finisterre Range, Yawan, $1740 \mathrm{~m}$, living accession NS11-218, vouchered at Ukarumpa on 21 Jun 2012 as Simonsson Juhonewe N. \& Juhonewe, F. NS0039L (LAE, SING); cultivated plant grown on from Finisterre Range, Yawan, $1800 \mathrm{~m}$, living accession NS11-224, vouchered at Ukarumpa on 21 Jun 2012 as Simonsson Juhonewe, N. \& Juhonewe, F. NS0040L (LAE); Huon Peninsula, Hoboc, 1830 m, 24 Dec 2011, Simonsson Juhonewe, N. \& Juhonewe, F. NS0015H (LAE) (living accession NS11-333); cultivated plant grown on from Huon Peninsula, Hoboc, $1450 \mathrm{~m}$, living accession NS11-245, vouchered at Ukarumpa on 8 Jun 2012 as Simonsson Juhonewe, N. \& Juhonewe, F. NS0035L (LAE); Waria Valley, Saureli, 1700 m, 1 Mar 2012, Simonsson Juhonewe, N., Juhonewe, F., Allison, A. \& James, S. NS0022H (LAE) (living accession NS12-096); cultivated grown on from Waria Valley, Saureli, 1700 m, living accession NS12-103, vouchered at Ukarumpa on 21 Jun 2012 as Simonsson Juhonewe, N. \& Juhonewe, F. NS0041L (LAE, SING).

Notes. This new species is morphologically similar to the as yet unresolved Hoya ischnopus complex, but is easily distinguished by the raised, conspicuous reticulate secondary veins on the leaves, especially when young, which makes it easy to identify even when not in flower. The venation of the leaves is most raised and reticulate in the populations from the middle of Finisterre and Saruwaged ranges, and less raised in the populations from the area where the Central Range meets the Owen Stanley Range. Also its pedicels are more slender, bearing flowers $16-22 \mathrm{~mm}$ in diameter, and the corona lobes are ovate-elliptic with rounded to obtuse (rarely acute) outer processes. Species in the Hoya ischnopus-complex have plain leaves lacking the raised venation, stiffer peduncles, flowers $<1.5 \mathrm{~cm}$ in diameter, and the corona lobes are rhomboid with acute outer processes. Hoya edholmiana is only found above $1400 \mathrm{~m}$ while species in the Hoya ischnopus complex can be found from sea level to $1400 \mathrm{~m}$.

Hoya evelinae Simonsson \& Rodda, sp. nov.

Similar to Hoya epedunculata Schltr. in having much reduced peduncles, but differs in having peduncles along climbing stems, leaves $<8 \mathrm{~cm}$ and (narrowly) elliptic corona lobes, while $H$. epedunculata has terminal peduncles, leaves $>8 \mathrm{~cm}$ in length and obovate corona lobes. - TYPE: Papua New Guinea, Chimbu-Gulf Province, Crater Mt. Wildlife Management Area, near junction between Wara O and Pio River. 440460 m, 30 March 1997, Takeuchi, W. 11941 (holotype A; isotypes K [K000224390], L, LAE, US). (Fig. 10, 11)

Epiphytic climber with white latex in all vegetative parts, glabrous. Stems up to 5 $\mathrm{m}$ long, cylindrical, 1-3 $\mathrm{mm}$ in diameter, green; older stems lignified, up to $5 \mathrm{~mm}$ in diameter, greyish brown, internodes $2-10(-25) \mathrm{cm}$ long. Adventitious roots sparsely 
scattered along the stems. Leaves often held horizontally, petiolate; petiole terete, 1-3 $\times 0.5 \mathrm{~mm}$; lamina elliptic-ovate, coriaceous, 5-10 × 2-3(-4) cm, medium green on both surfaces, apex acute to caudate, base round to attenuate; venation pinnate, midrib depressed on adaxial surface, secondary veins obscure. Inflorescence one per node, extra-axillary, pseudo-umbellate, consisting of 2-5 flowers; peduncle terete, much reduced, c. $1 \times 1 \mathrm{~mm}$, older peduncles forming a rachis from previous flowerings, pedicels terete, $2-3 \mathrm{~cm} \times 0.5-1 \mathrm{~mm}$ in diameter, light green, glabrous. Calyx c. $5 \mathrm{~mm}$ in diameter, calyx lobes ovate, c. $2 \times 0.7 \mathrm{~mm}$, apex acute-rounded. Corolla broadly campanulate, almost rotate, c. $3 \mathrm{~cm}$ in diameter ( $2 \mathrm{~cm}$ when dry), pale pink, translucent; tube c. $1 \mathrm{~cm}$ (c. 0.5 when dry), lobes broadly triangular, c. $1 \times 1.2 \mathrm{~cm}$, thinly pubescent inside, almost glabrous near centre, outside glabrous, margins recurved, apex obtuse. Corona staminal, c. $2 \mathrm{~mm}$ high, c. $8 \mathrm{~mm}$ in diameter, fleshy, creamy yellow with maroon centre; lobes from above (narrowly) elliptic, c. $4 \times 1.8 \mathrm{~mm}($ c. $3 \times 1$ when dry), inner processes acuminate, outer processes rounded (acute), with basal revolute margins along the entire length of the corona lobe, not basally fused with filament tube. Pollinia oblong c. 330-380 × 120-200 $\mu \mathrm{m}$, with sterile edge, corpusculum oblong with constriction in the middle, $150-200 \times 100-150 \mu \mathrm{m}$, caudicles attached at the lower half of the corpusculum, $70-80 \times$ c. $50 \mu \mathrm{m}$. Ovary conical, 2-3 mm long, glabrous. Fruit and seed not observed.

Distribution. The species is only known from the type locality on Crater Mountain and from Black River in Western Province. It may be locally endemic as it has not been recorded elsewhere, neither in herbaria nor during the first author's fieldwork.

Etymology. Named after the late Mrs Evelina Eriksson (1932-2009) of Sweden who supported the first author's work in PNG.

Habitat and ecology. A climber in riverine forest, often growing on trees or shrubs, or even on mossy rocks, near or above streams. Not observed on taller trees or in sunnier and drier areas, only in shade or filtered sunlight. Locally common.

Provisional IUCN conservation assessment. Critically Endangered CR B1a,b(iii) (IUCN, 2016). The species co-occurs with Hoya brassii at the type locality where it is locally common. However much of PNG Western Province's lowland rainforest has been or is being logged (Shearman et al., 2009). The type locality is not inside a protected area and may be lost in the near future.

Additional specimens examined. PAPUA NEW GUINEA: Western Province: Black River, near Dahamo, 1 Mar 2011, Simonsson Juhonewe, N. \& Juhonewe, F. NS0005H (LAE, SING) (living accession NS11-115).

Notes. In Papuasia the only other species with much reduced peduncles are Hoya epedunculata and Hoya brassii. Hoya evelinae can be separated from $H$. epedunculata because it produces peduncles almost at every node when mature, and often has numerous inflorescences with simultaneously open flowers, leaves $<8 \mathrm{~cm}$ long and 

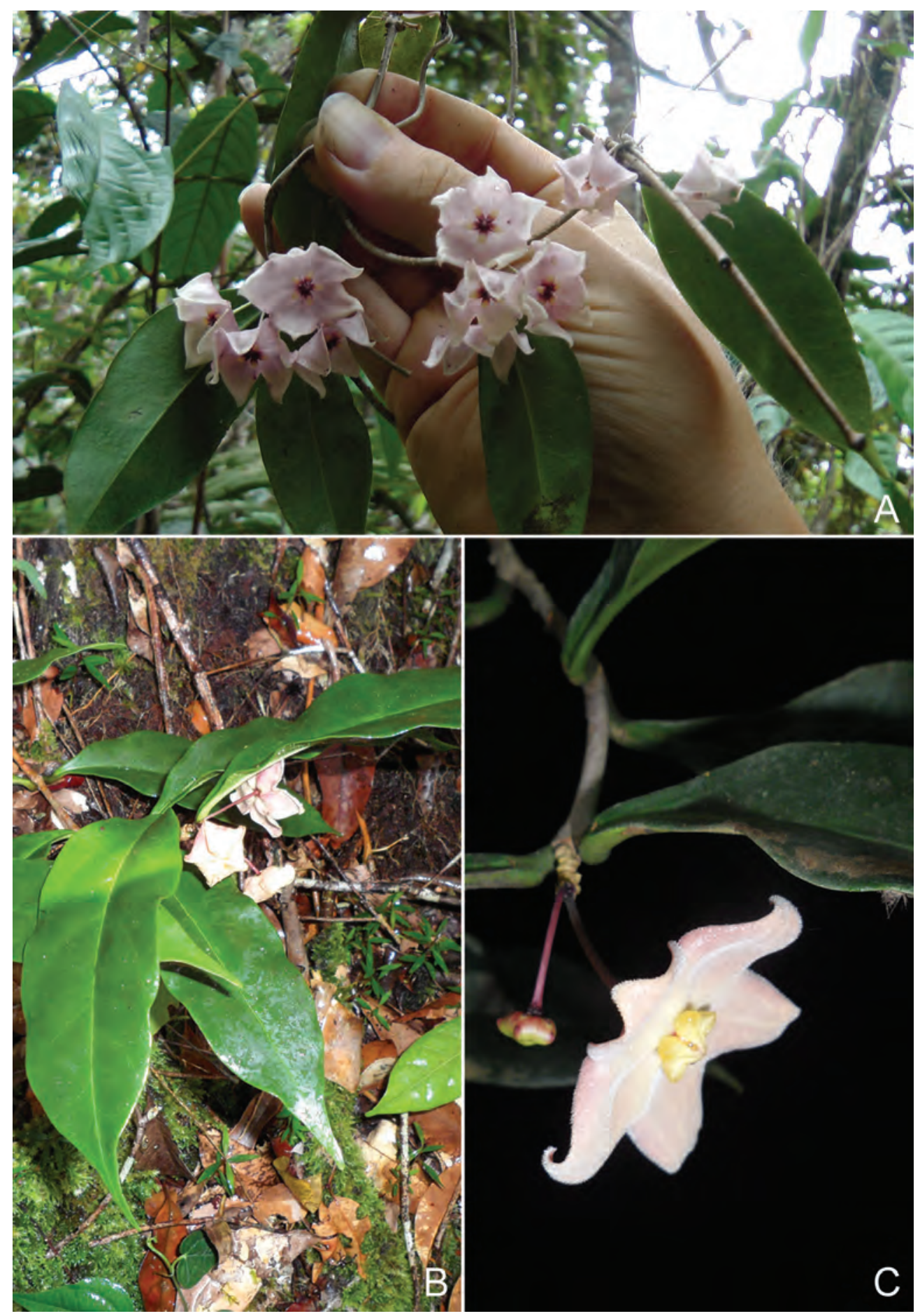

Fig. 10. A. Hoya evelinae Simonsson \& Rodda inflorescences with multiple flowers open. B. C. Hoya epedunculata Schltr. inflorescences with a single flower open. (Photos: N. Simonsson Juhonewe) 


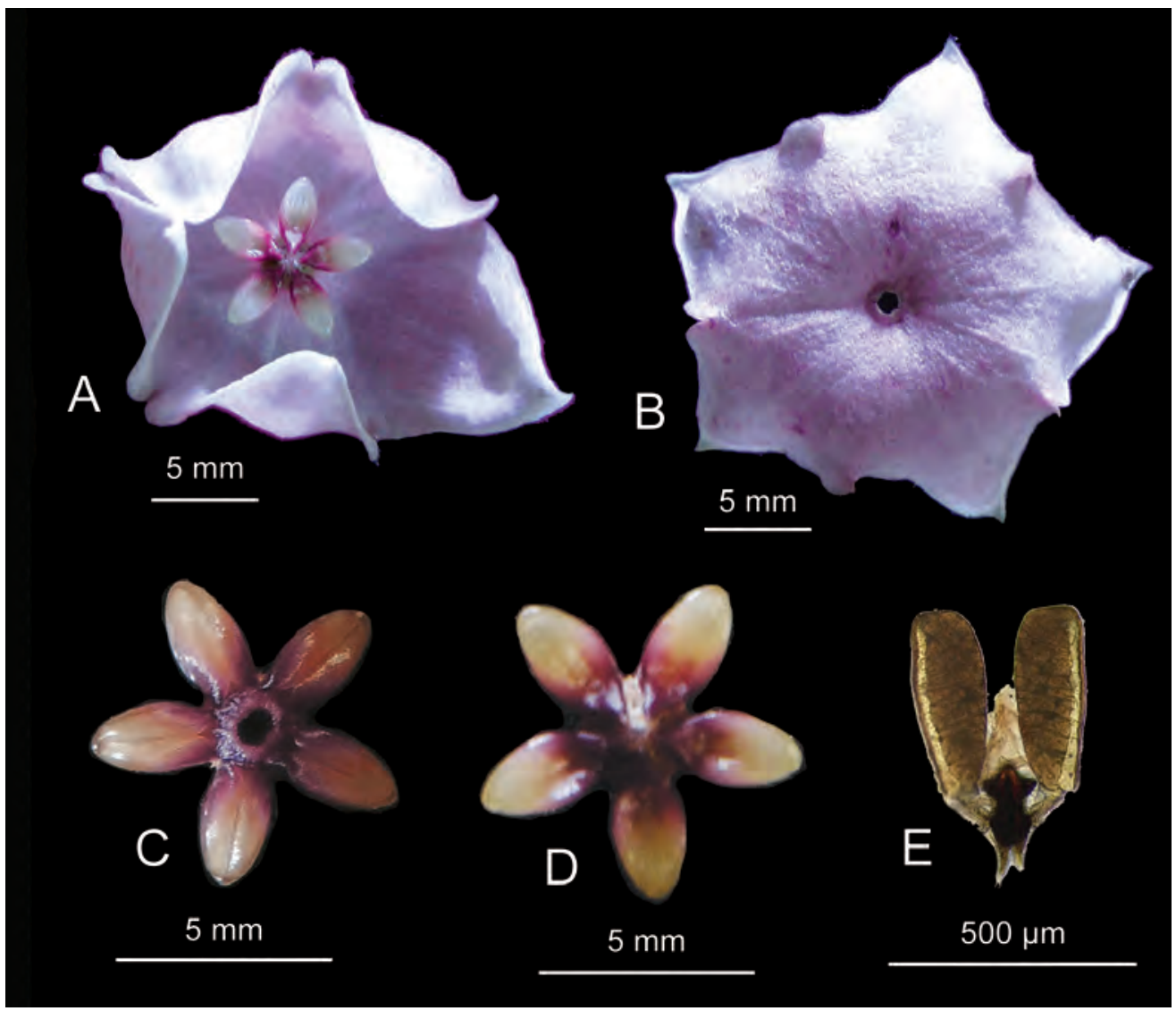

Fig. 11. Hoya evelinae Simonsson \& Rodda. A. flower, top view. B. Corolla from underneath. C. Corona, from underneath. D. Corona, top view. E. Pollinarium. All from Simonsson Juhonewe, N. \& Juhonewe, F. NS0005H. (Photos A-D: N. Simonsson Juhonewe; E: M. Rodda)

corona lobes (narrowly) elliptic, while $H$. epedunculata has fewer peduncles, often terminal, leaves $>8 \mathrm{~cm}$ in length and its corona lobes are obovate. Hoya evelinae can be separated from Hoya brassii because its flowers are $>2 \mathrm{~cm}$ in diameter (vs. 1-1.5 cm).

Hoya juhoneweana Simonsson \& Rodda, sp. nov.

Similar to Hoya urniflora in the sunken leaf venation and bullate leaf surface, but Hoya urniflora has corollas c. $1.5 \mathrm{~cm}$ wide whereas $H$. juhoneweana has corollas $>2.5 \mathrm{~cm}$ wide. - TYPE: Papua New Guinea, Morobe Province, Huon Peninsula, Hoboc, primary riverine forest, 1500 m, 31 December 2011, Simonsson Juhonewe, N. \& Juhonewe, F. NS0016H (holotype LAE; isotype SING) (living accession NS11363). (Fig. 12-14). 
subsp. juhoneweana

Pendulous epiphyte with white latex in all vegetative parts. Stems up to $5 \mathrm{~m}$ long, flexible, (horizontal) pendulous, cylindrical, 1-1.5 $\mathrm{mm}$ in diameter, green, pubescent with very stiff, spreading $0.5 \mathrm{~mm}$ or longer stiff hairs; older stems lignified, up to $3 \mathrm{~mm}$ in diameter, greyish brown, often glabrous; internodes 3-6(-25) cm long. Adventitious roots scattered along the stems. Leaves pendulous, petiolate; petiole terete, $2-10 \times 1-1.5 \mathrm{~mm}$, green, covered with very stiff, erect, $1 \mathrm{~mm}$ or longer hairs; lamina elliptic-ovate, chartaceous, stiff and brittle when mature, 3-8 $\times 2-4 \mathrm{~cm}$, bright green on adaxial surface, light green on abaxial surface, both surfaces covered by very stiff, erect, $1 \mathrm{~mm}$ or longer hairs, especially near base and abaxial midrib, apex cuspidate-caudate, base round to attenuate, margin entire and revolute; venation pinnate, midrib much depressed on adaxial surface, secondary veins $2-5$ each side, evident and often depressed, giving the lamina a bullate appearance, anastomosing near the leaf margin, branching from the midrib at $45-80^{\circ}$; leaf colleters one pair at the lamina base, greyish white. Inflorescence one per node, extra-axillary, positively geotropic, pseudo-umbellate, consisting of 1-5 flowers; peduncle terete, $1-3 \mathrm{~cm} \times$ c. $1 \mathrm{~mm}$, older peduncles forming a rachis from previous flowerings, new peduncles hirsute, often almost glabrous in old peduncles; pedicels terete, c. $2 \mathrm{~cm} \times$ c. $1 \mathrm{~mm}$ in diameter, light green, often spotted in purple near calyx, glabrous (sparsely pubescent). Flower buds globular with flattened apex, creamy white with pink and purple dots. Calyx c. $5 \mathrm{~mm}$ in diameter, calyx lobes ovate-lanceolate, c. $1 \times 0.7 \mathrm{~mm}$, apex acute, purple spotted. Corolla deeply campanulate, fleshy, $2.5-3 \mathrm{~cm}$ in diameter, cream coloured with a slightly greenish hue in centre fading to a pinkish hue on lobes penetrating from the outer surface; tube $1-1.5 \mathrm{~cm}$ long $\times 1.5-2 \mathrm{~cm}$ in diameter, lobes broadly triangular, c. $1 \times 1.5 \mathrm{~cm}$, thickly pubescent inside, usually almost glabrous near centre, outside glabrous, margins recurved, apex acute. Corona staminal, c. 5 $\mathrm{mm}$ high, c. $9 \mathrm{~mm}$ in diameter, fleshy, cream coloured with a light green protruding style-head; lobes round from above, c. $3.5 \times 3 \mathrm{~mm}$, inner processes much reduced and linear, $0.5 \times 0.2 \mathrm{~mm}$, each outer process with a sharp central ridge and a basal longitudinal protrusion on each side running from the base of the guide rails up to the apex, with basal revolute margins right up to the apex. Style-head mamillate, higher than anther appendages. Pollinia oval, 400-500 $\times 280-320 \mu \mathrm{m}$, no sterile edge, retinaculum ovoid, $350-400 \times$ c. $300 \mu \mathrm{m}$, caudicles attached at the base of retinaculum, broadly triangular, $100-150 \times$ c. $100 \mu \mathrm{m}$. Ovary conical, c. $3 \mathrm{~mm}$ long, narrowing down at $2 \mathrm{~mm}$ from the base; each carpel c. $1.3 \mathrm{~mm}$ wide at base, light green, glabrous. Fruit and seed not observed.

Distribution. Only found near the remote village of Hoboc at 1500-1800 m. Four individuals of Hoya juhoneweana ssp. juhoneweana were originally seen, of which two had disappeared when their locality was revisited for the last time in 2012 due to expanding subsistence gardens and degradation of the riverine forest by the local villagers. Hoya urniflora was collected at the same locality and is abundant there. 


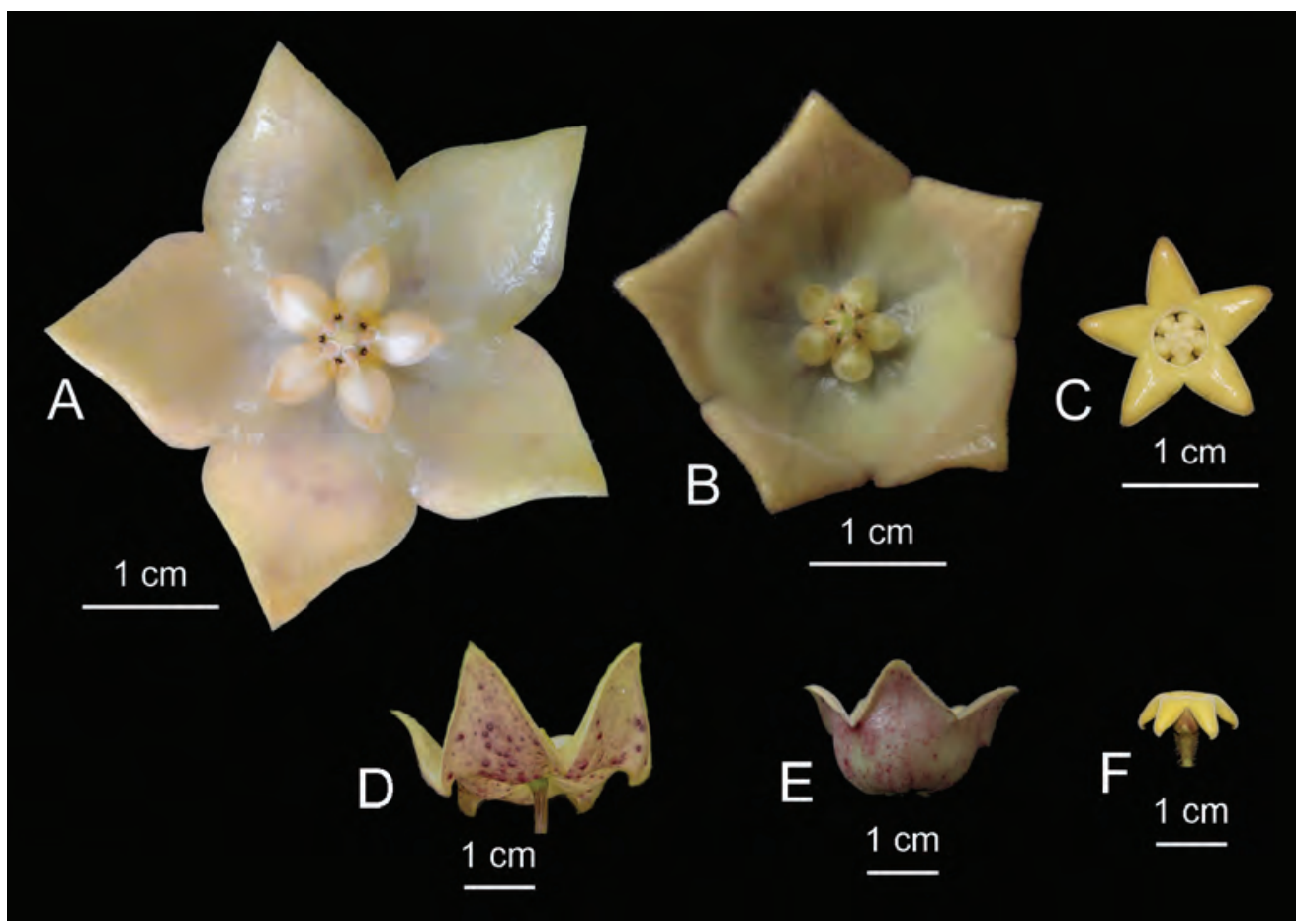

Fig. 12. Comparison between Hoya juhoneweana ssp. lindforsiana Simonsson \& Rodda (A, D, from Simonsson Juhonewe, N. \& Juhonewe, F. NS0068L), Hoya juhoneweana ssp. juhoneweana Simonsson \& Rodda (B, E, from Simonsson Juhonewe, N. \& Juhonewe, F. NSO016H) and Hoya urniflora (P.I.Forst.) Simonsson \& Rodda (from Simonsson Juhonewe, N. \& Juhonewe, F. NS0102L). A-C. Corolla from above. D-F. Corolla, side view. (Photos: F. Juhonewe)

Etymology. Named after the first author's colleague, Foreting Juhonewe, who is also from Hoboc village. He has been of great importance for this research. He has eagerly tried to find more of this rare and diminishing Hoya and promoted its conservation in situ amongst his clan's people.

Habitat and ecology. This taxon co-occurs with two other new species described here, H. edholmiana and H. urniflora. At the type locality this taxon and Hoya urniflora inhabit only mossy riverine forest on mature trees in primary forest and were not found in the adjacent mature secondary forest and in the subsistence gardens. The cooccuring taxon Hoya edholmiana, however, is more abundant and also occasionally found in mature secondary forest.

Provisional IUCN conservation assessment. Critically Endangered CR B1ab(ii,iii,v), D (IUCN, 2016). This subspecies has only been recorded at the type locality, despite extensive field expeditions in the Finisterre-Sarawaged Range by the first author and 

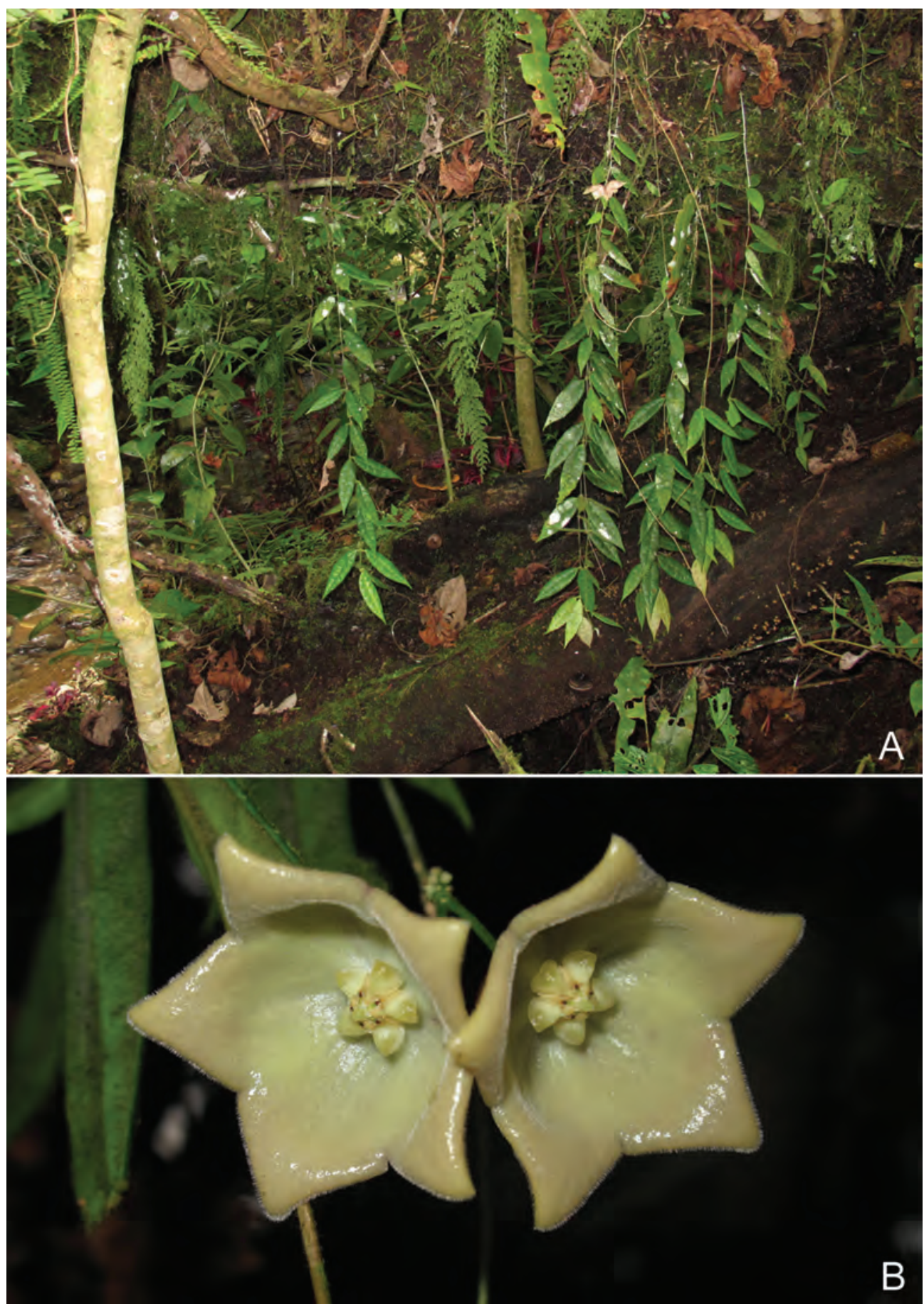

Fig. 13. Hoya juhoneweana ssp. juhoneweana Simonsson \& Rodda in habitat. A. The pendent epiphyte at Hoboc, the type locality. B. Inflorescence with two open flowers. All based on Simonsson Juhonewe, N. \& Juhonewe, F. NS0016H. (Photos: A: S. Pimm Lyon; B: N. Simonsson Juhonewe). 


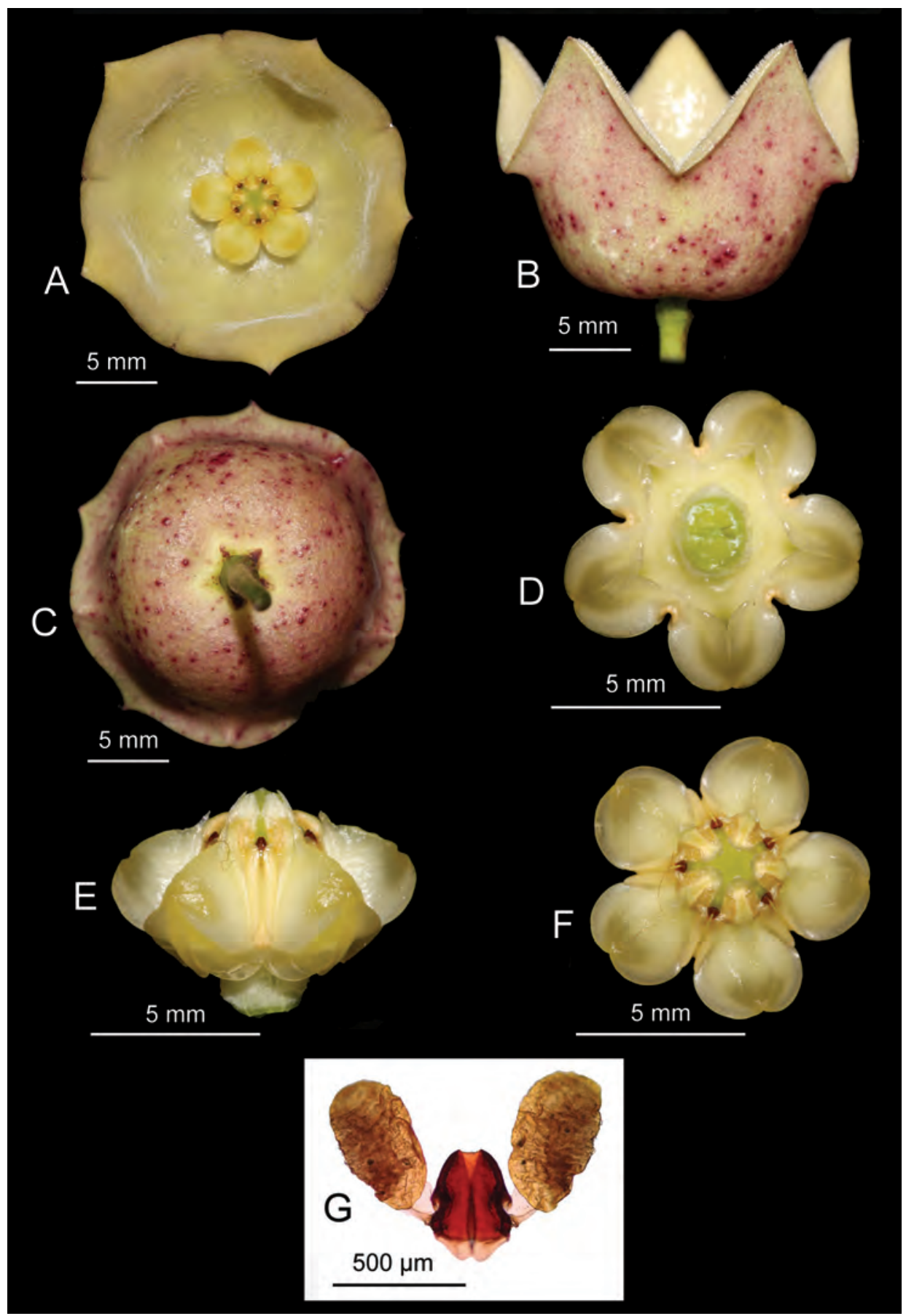

Fig. 14. Hoya juhoneweana subsp. juhoneweana Simonsson \& Rodda. A. Flower from above. B. Flower, side view. C. Corolla and calyx, from underneath. D. Corona, from underneath. E. Corona, side view. F. Corona, top view. G. Pollinarium. All based on Simonsson Juhonewe, $N$. \& Juhonewe, F. NS0016H. (Photos A-F: F. Juhonewe; G: M. Rodda) 
many other botanists (Vollering et al., 2016). The population size at the type locality was reduced from 2010 to 2012 due to expanding subsistence agriculture.

Additional specimens examined. PAPUA NEW GUINEA: Morobe Province: Huon Peninsula, Hoboc, 1830 m, 24 December 2011, living accession NS11-332, vouchered at Ukarumpa on 2 June 2013 as Simonsson Juhonewe, N. \& Juhonewe, F. NS0074L (LAE).

Notes. Hoya juhoneweana is easily distinguished from the large majority of Hoya species due to the conspicuous sunken venation causing a characteristic bullate leaf surface, and by its dense cover of $>1 \mathrm{~mm}$ long hairs on all vegetative parts, especially when young. Its leaves are, however, indistinguishable from Hoya urniflora. The two species can be separated when sterile because Hoya juhoneweana is pendulous while H. urniflora is a climber. When in flower, the two taxa are easily distinguished, as Hoya juhoneweana has $>2.5 \mathrm{~cm}$ wide corollas whereas the corollas of $H$. urniflora are c. 1.5 $\mathrm{cm}$ wide. Interestingly, the two species co-exist and intermingle at the same locality leading us to initially assume they were a single species during early expeditions. Upon flowering in cultivation, however, we realised there were two distinct species growing together in the same area.

Hoya juhoneweana subsp. lindforsiana Simonsson \& Rodda, subsp. nov.

Similar to Hoya juhoneweana ssp. juhoneweana and Hoya urniflora in having sunken leaf venation and bullate leaf surface, but easily distinguished by the diameter of its corolla $(4-5 \mathrm{~cm})$, whereas it is $2.5-3 \mathrm{~cm}$ in $H$. juhoneweana subsp. juhoneweana and c. $1.5 \mathrm{~cm}$ in Hoya urniflora. - TYPE: Papua New Guinea, Madang Province, Mebu, disturbed primary riverine forest, $1300 \mathrm{~m}$, living accession NS12-279, vouchered at Ukarumpa on 9 March 2013, Simonsson Juhonewe, N. \& Juhonewe, F. NS0068L (holotype LAE; isotype SING). (Fig. 12, 15)

Slender pendulous epiphyte with occasional twining branches, with white latex in all vegetative parts. Stems up to $5 \mathrm{~m}$ long, flexible, often pendulous, cylindrical, 1-1.5 $\mathrm{mm}$ in diameter, green, pubescent with very stiff, spreading, $0.5 \mathrm{~mm}$ or longer hairs; older stems lignified, up to $3 \mathrm{~mm}$ in diameter, greyish brown, pubescent or glabrous; internodes 3-6(-25) cm long. Adventitious roots scattered along the stems. Leaves pendulous, petiolate; petiole terete, $2-10 \times 1-1.5 \mathrm{~mm}$, green, covered with very stiff, erect $1 \mathrm{~mm}$ or longer hairs; lamina elliptic-ovate, chartaceous, stiff and brittle when mature, 3-8 $\times 2-4 \mathrm{~cm}$, bright green on adaxial surface, light green on abaxial surface, both surfaces covered by very stiff, erect, $1 \mathrm{~mm}$ or longer hairs, especially near base and abaxial midrib, apex cuspidate to acute, base round to attenuate, margin recurved; venation pinnate, midrib depressed on adaxial surface, secondary veins 2-5 each side, evident and often depressed, giving the lamina a bullate appearance, anastomosing near the leaf margin, branching from the midrib at $45-80^{\circ}$; leaf colleters one pair at each lamina base, greyish white. Inflorescence one per node, extra-axillary, 
positively geotropic, pseudo-umbellate, consisting of 1-5 flowers; peduncle terete, $1-3 \mathrm{~cm} \times$ c. $1 \mathrm{~mm}$, older peduncles forming a rachis from previous flowerings, new peduncles hirsute, old peduncles often almost glabrous; pedicels terete, $2-3 \mathrm{~cm} \times \mathrm{c}$. $1 \mathrm{~mm}$ in diameter, light green, often spotted in purple near calyx, glabrous (sparsely pubescent). Flower buds apically flattened, creamy white with pink and purple dots. Calyx c. $5 \mathrm{~mm}$ in diameter, calyx lobes ovate-lanceolate, c. $2 \times 1.5 \mathrm{~mm}$, apex acute and ciliate. Corolla broadly campanulate, almost rotate, fleshy, 4-5 cm in diameter, cream-white coloured with a slightly greenish-yellow translucent hue, outside often pink-maroon if exposed to bright light; tube 1.2-1.5 cm long, glabrous to puberulous within, glabrous near centre, outside glabrous; lobes broadly triangular with upturned auricles at the sinuses, c. $1.5 \times 1.5 \mathrm{~cm}$, margins entire and slightly revolute, apex acute, inside sparsely pubescent, outside glabrous. Corona staminal, c. $6 \mathrm{~mm}$ high, c. $14 \mathrm{~mm}$ in diameter, fleshy, cream-white; lobes broadly elliptic, c. $6 \times 4.5 \mathrm{~mm}$, inner processes much reduced and linear, $0.8 \times 0.3 \mathrm{~mm}$, each outer process with a sharp central ridge and a basal longitudinal protrusion on each side running from the base of the guide rails up to the apex, with basal revolute margins right up to the apex, not basally fused with filament tube. Style-head basal convex process narrowed into a raised convex tip, much exposed and not hidden by anther appendages, light green. Pollinia elliptic, 900-950 × 400-500 $\mu \mathrm{m}$, without sterile edge, corpusculum ovate, 500-600 × 400$450 \mu \mathrm{m}$, caudicles attached at lower half of corpusculum, 300-350 × 130-150 $\mu \mathrm{m}$. Ovary conical, c. $3 \mathrm{~mm}$ long, narrowing at $2 \mathrm{~mm}$ from the base; each carpel c. $1.5 \mathrm{~mm}$ wide at base, light green, glabrous. Fruit and seed not observed.

Distribution. Only found in the Mebu area, Madang Province at $1300 \mathrm{~m}$ altitude, where 12 specimens were sighted at only one site near a deep, moist montane valley. It has never been recorded outside that locality, even in other parts of the same mountain range.

Etymology. Named after Constantinus Lindfors in Sweden, a supporter of the first author's work in PNG.

Habitat and ecology. Hoya juhoneweana subsp. lindforsiana inhabits mossy riverine primary forests where it grows on large mature trees but is absent in the adjacent mature but drier secondary forests and in the subsistence gardens. The co-occuring taxa Hoya oreostemma Schltr. and Hoya solaniflora are more abundant and grow well on younger trees along paths and in mature secondary forest with more sunlight. The inability to recolonise secondary habitats has also been observed for the two similar taxa $H$. juhoneweana subsp. juhoneweana and $H$. urniflora.

Provisional IUCN conservation assessment. Critically Endangered CR B2a,b(iii), D (IUCN, 2016). Despite extensive field expeditions in the Finisterre-Sarawaged Range by the first author and many other botanists (Vollering et al., 2016) this subspecies has only been recorded at the type locality, where a single population including only 12 individuals was seen in an area of $<1 \mathrm{~km}^{2}$. 


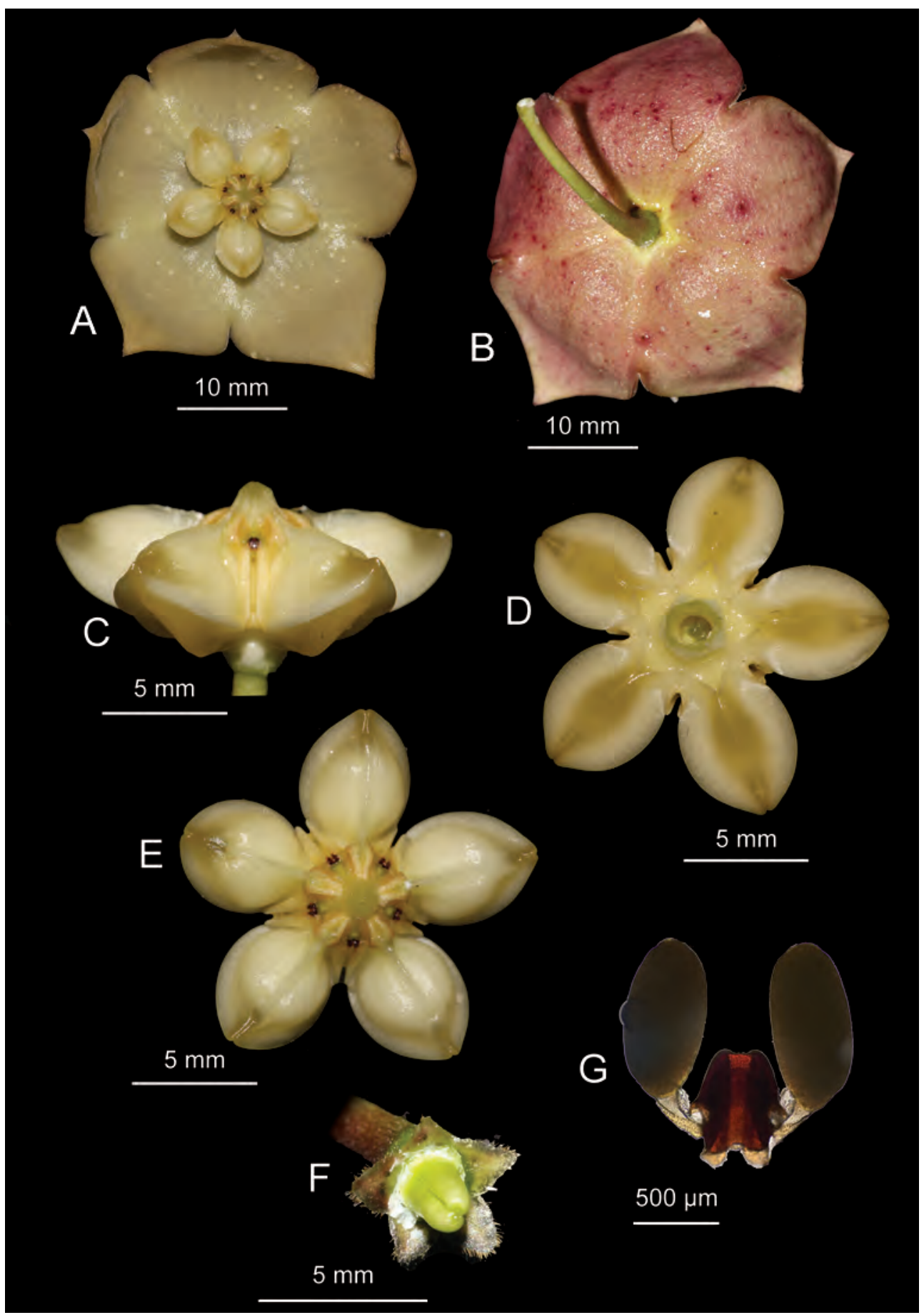

Fig. 15. Hoya juhoneweana subsp. lindforsiana Simonsson \& Rodda. A. Flower from above. B. Corolla and calyx, from underneath. D. Corona, side view E. Corona, top view. F. Calyx and ovaries. G. Pollinarium. All based on Simonsson Juhonewe, N. \& Juhonewe, F. NS0068L. (Photos A-F: N. Simonsson Juhonewe; G: M. Rodda) 
Notes. In vegetative appearance Hoya juhoneweana subsp. lindforsiana is not easily distinguished from the typical subspecies. When in flower, however, they are easily distinguished, even in the bud stage. Hoya juhoneweana subsp. juhoneweana has globular buds with flattened apices, a more narrowly campanulate corolla, $2.5-3 \mathrm{~cm}$ wide, and a corona c. $0.9 \mathrm{~cm}$ wide, whereas $H$. juhoneweana subsp. lindforsiana has wide flattened buds, a broadly campanulate, almost rotate corolla, 4-5 cm wide, and corona c. $1.3 \mathrm{~cm}$ wide. The two subspecies are so far only known from their respective separate deep montane valleys on each end of the Finisterre-Sarawaged Range, about $170 \mathrm{~km}$ apart.

Hoya krusenstierniana Simonsson \& Rodda, sp. nov.

Similar to Hoya solaniflora Schltr. being thin wiry climbers with small leaves, $1-7 \times$ $0.5-4.5 \mathrm{~cm}$, and even flowering herbarium material is difficult to distinguish. In the living state, however, it is easily distinguished by its purple to rich crimson flowers and by its scent, which is reminiscent of peeled unripe green bananas, whereas Hoya solaniflora bears pale flowers in shades of white-yellow-pink, and with a scent more similar to Gardenia jasminoides J.Ellis. - TYPE: Papua New Guinea, Morobe Province, Mount Kaindi, $7^{\circ} 20^{\prime} \mathrm{S} 146^{\circ} 45^{\prime} \mathrm{E}$, edge of mossy forest, climber straggling in regrowth, $7650 \mathrm{ft}$ [c. $2330 \mathrm{~m}$ ], 2 November 1966, Ridsdale, C.E. NGF 30193 (holotype LAE; isotypes L n.v., BRI n.v., CANB n.v.). (Fig. 16, 17)

Epiphytic climber with white exudate in all vegetative parts. Stems cylindrical, 1-5 $\mathrm{m}$ long, 1-2 mm in diameter, dark green, glabrous or sparsely pubescent; older stems leafless, up to $3 \mathrm{~mm}$ in diameter, greyish brown, glabrous; internodes $1-10(-20) \mathrm{cm}$ long. Leaves petiolate; petiole terete, $3-10 \times$ c. $1 \mathrm{~mm}$ in diameter, green, pubescent (glabrescent with age); lamina ovate-lanceolate, thick, fleshy, 1.5-7.5 × 1-3.6 cm, bright to dark green on adaxial surface, light green on abaxial surface, glabrous or sparsely pubescent on both surfaces when young, glabrous when old, apex obtuse to narrowly acuminate to cuspidate, base round to attenuate with basal colleters, margin sometimes recurved; venation pinnate, midrib depressed on adaxial surface, secondary veins 2-4 each side, often slightly depressed on adaxial surface and anastomosing near the leaf margin, branching at $30-80^{\circ}$. Inflorescences one per node, extra-axillary, positively geotropic, flat to convex, consisting of 5-15 flowers; peduncle terete, peduncle (0.5)1.5-7 cm $\times 0.7-1 \mathrm{~mm}$, older peduncles developing a rachis from previous flowerings, new peduncles sparsely pubescent, older peduncles often glabrous; pedicels terete, 1-3 cm $\times 0.5-0.7 \mathrm{~mm}$ in diameter, green, pubescent. Flower buds apically flattened, green to maroon. Flower scent like peeled green, unripe bananas. Calyx 4-6 mm in diameter, lobes ovate-elliptic, $1.5-2 \times 1-1.5 \mathrm{~mm}$, apex rounded to acute, glabrous on both sides, margin ciliate; basal colleters absent. Corolla rotate, slightly concave, c. $1.8 \mathrm{~cm}$ diameter (c. $2 \mathrm{~cm}$ when flattened), pink to rich crimson; tube c. $6 \mathrm{~mm}$ long, lobes triangular to broadly acuminate, c. $5 \times 7 \mathrm{~mm}$, adaxially thickly pubescent, abaxially glabrous, margins entire, apex acute. Corona staminal 2-3 mm high, c. $7 \mathrm{~mm}$ in diameter, fleshy, intensely crimson; lobes variable in shape from broadly ovate to lanceolate, even within the same population, $4 \times 1.5-2 \mathrm{~mm}$, inner processes 


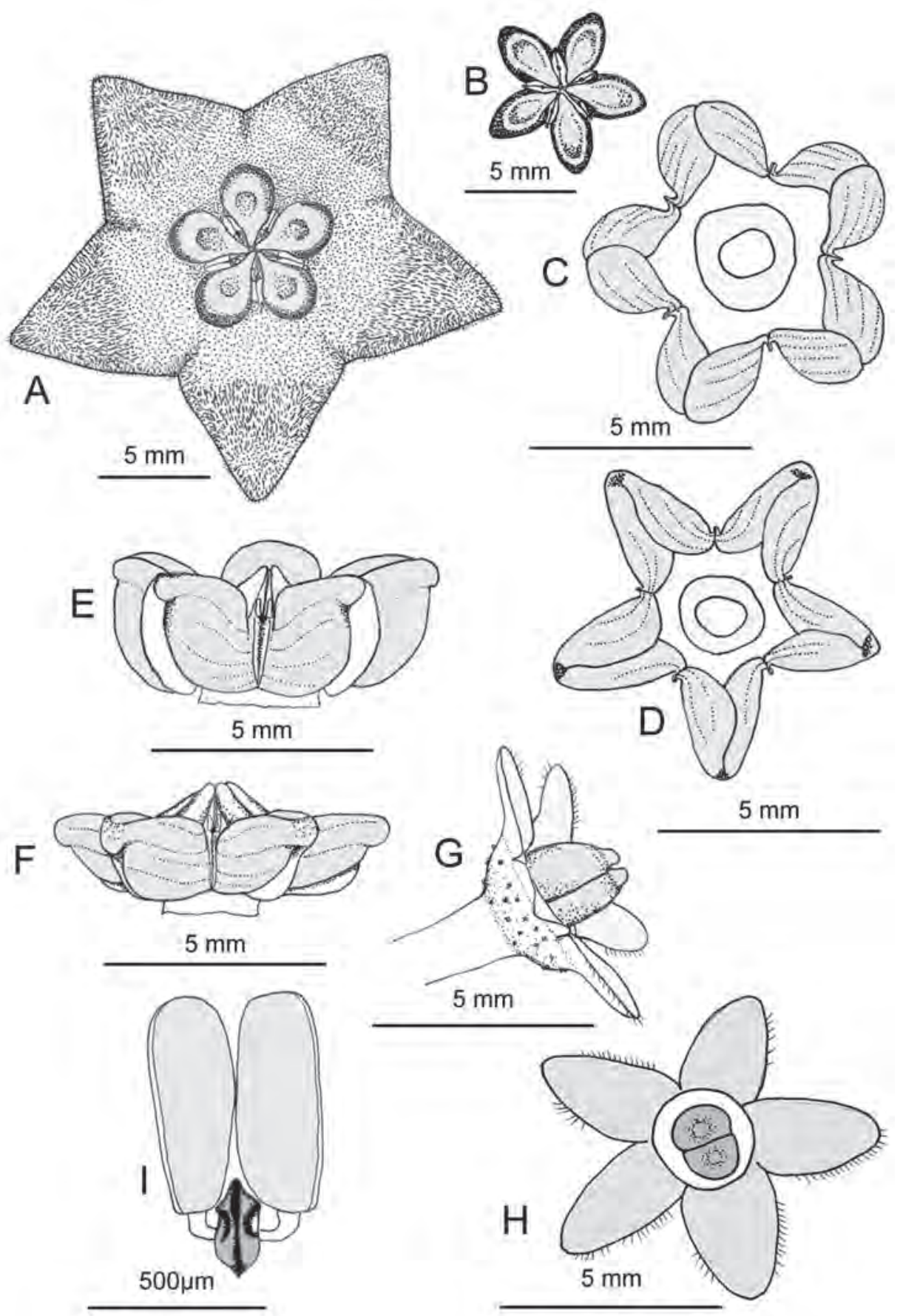

Fig. 16. Hoya krusenstierniana Simonsson \& Rodda. A. Flower, top view. B. Corona, top view. C, D. Corona, from underneath. E, F. Corona, side view. G. Calyx and ovaries, side view. H. Calyx and ovaries, top view. I. Pollinarium. A, C, E, G, H from Simonsson Juhonewe, N. \& Juhonewe, F. NS0019H; B, D, F, I from Simonsson Juhonewe, N. \& Juhonewe, F. NS0020H. (Drawing: M. Rodda) 


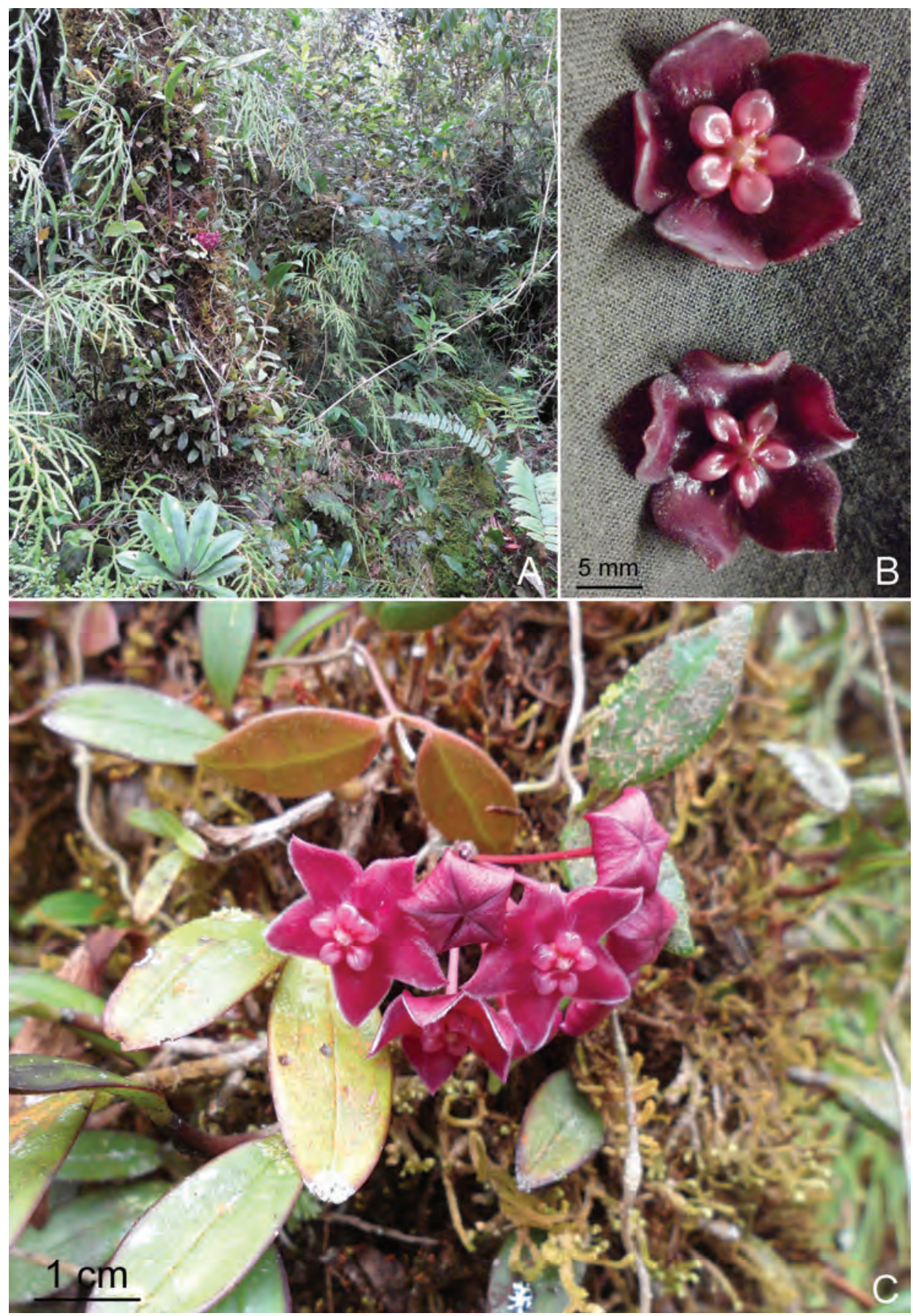

Fig. 17. Hoya krusenstierniana Simonsson \& Rodda in habitat on Mount Kaindi. A. Mature plant growing on tree trunks in mossy forest. B. Flowers from two different plants showing variation in the shape of the corona (above from Simonsson Juhonewe, N. \& Juhonewe, F. NS0019H, below from from Simonsson Juhonewe, N. \& Juhonewe, F. NS0020H). C. Inflorescence. (Photos: F. Juhonewe) 
elongated, flat to erect, outer processes apex rounded to acute when observed from above, slightly erect both higher and lower than inner corona apex, grooved between inner and outer processes, not fused with filament tube, with basal revolute margins. Style-head convex, hidden by both anther appendages and inner corona processes. Pollinia oblong, $650 \times 270 \mu \mathrm{m}$, with sterile edge, corpusculum oblong, c. $310 \times 170$ $\mu \mathrm{m}$, caudicles attached at the sides of corpusculum, c. $100 \mu \mathrm{m}$ long. Ovary conical with a rounded to distinct mammillate tip, c. $2 \mathrm{~mm}$ long; each carpel c. $1 \mathrm{~mm}$ wide at base, glabrous. Fruits c. $18 \mathrm{~cm}$ long, $0.5 \mathrm{~cm}$ wide, purplish. Seeds not observed.

Distribution. Recorded primarily at 1800-2600 m on Mount Kaindi in Morobe Province, Mount Pimbilyo in Enga Province and along the Kokoda Track in Central and Oro Provinces.

Etymology. Named after the Krusenstiern family, supporters of the first author's work in PNG.

Habitat and ecology. Hoya krusenstierniana has the highest altitudinal record for Hoya in Malesia, as it grows at 1800-2600 m. The second highest record for the genus is Hoya nyhuusiae Kloppenb. which is found up to $2200 \mathrm{~m}$ on Mt Kinabalu in Sabah (Borneo). On the summit of Mount Kaindi, Hoya krusenstierniana is found creeping and twining on dwarf mossy trees or on a thick layer of moss on the ground, both under shade and in fully exposed locations. It is also found twining among taller growth where it produces bigger leaves on the slopes near the summit or towards Edie Creek mine. It flowers throughout the year.

Provisional IUCN conservation assessment. Endangered EN B1ab(iii) (IUCN, 2016). The type locality was already disturbed when the species was first collected in the 1960s; however it was still abundant during the most recent collection in 2012. However, now the area faces a rapidly expanding population so when the first author was there in 2012, people had begun settling down on the summit of Mount Kaindi and were in process of clearing both the primary and secondary forest to create subsistence gardens. This, in combination with people practising slash-and-burn agriculture downhill which can lead to rapidly spreading out-of-control fires, may pose threats to the future of the type locality. However, the species has also been recorded on other mountain tops (Tari \& Reeve 4352, Carr 13714), suggesting it may be thriving on several of Papua New Guinea's uninhabited cold mountain tops too inaccessible for expeditions and most subsistence gardeners. The type locality has seen a decline in the population of Hoya krusenstierniana and only rather old collections are known from the other localities.

Additional specimens examined. PAPUA NEW GUINEA: Morobe Province: Mount Kaindi, $7^{\circ} 25^{\prime} \mathrm{S} 146^{\circ} 45^{\prime} \mathrm{E}$, Nothofagus forest understorey, $7500 \mathrm{ft}$ [c. $2285 \mathrm{~m}$ ], 9 Oct 1964, Womersley, J.S. NGF 19432 (LAE, L n.v., BRI n.v., CANB n.v.); Mount Kaindi, S 7 20, E 146 45, 6500 ft [c. 1980 m], 9 April 1965, Taylor, G. J. NGF 20965 (LAE, L n.v.); Mount Kaindi, 7²5'S $146^{\circ} 45^{\prime} \mathrm{E}$, regrowth of mossy forest, $7500 \mathrm{ft}$ [c. $2285 \mathrm{~m}$ ], 24 April 1965, Womersley, J.S. NGF 24514 (LAE); Edie Creek, $7^{\circ} 20^{\prime} \mathrm{S} 146^{\circ} 45^{\prime} \mathrm{E}$, vine on undergrowth, $6500 \mathrm{ft}$ [c. $1980 \mathrm{~m}$ ], 15 Jan 1966, Henty, E.E. NGF 27170 (LAE, L n.v.); Mount Kaindi, understorey of montane forest, 
7500 ft, 2 June 1967, Womersley, J.S. NGF 24966 (LAE); Mount Kaindi, steep slope in moss forest, twining in undergrowth, c. $8000 \mathrm{ft}$ [c. $2440 \mathrm{~m}$ ], 7 Jun 1968, Coode, M., Woods, $P$. \& Katik, P. NGF 32858 (LAE, L n.v., BRI n.v.); Mount Kaindi, near helicopter pad, $7^{\circ} 20^{\prime}$ S $146^{\circ} 45^{\prime} \mathrm{E}$, regrowth, $7500 \mathrm{ft}$ [c. $2285 \mathrm{~m}$ ], 18 Dec 1968, Vandenberg, J. NGF 42161 (A, LAE, L n.v., CANB n.v., K); Mount Kaindi, $7^{\circ} 23^{\prime} \mathrm{S} 146^{\circ} 42^{\prime} \mathrm{E}$, on side of road in disturbed area, climber over secondary species, $7200 \mathrm{ft}$ [c. $2195 \mathrm{~m}$ ], 26 Feb 1970, Streimann, H, \& Kairo, A. NGF 47516 (LAE, L n.v., BRI n.v.); Mount Kaindi, near summit, montane forest edge, $7800 \mathrm{ft}$ [c. 2380 m], 1 Jul 1972, Beamish, K. 33 (LAE); Mount Kaindi, 7²9'S 146²0'E, regrowth forest, 2438 m, 28 May 1974, Katik, P. \& Larivita, G. LAE 62075 (LAE,L n.v., BRI n.v.); Mount Kaindi, summit region, S $7^{\circ}$ E $146^{\circ}$, mossy forest, c. 2360 m, 28 Oct 1974, Allison, A. 273 (LAE); Mount Kaindi, near repeater station, $7^{\circ} 10^{\prime} \mathrm{S} 146^{\circ} 40^{\prime} \mathrm{E}$, Nothofagus dominated forest, 2400 m, 30 May 1977, Conn, B. \& Kairo, A. 168 (LAE, BFC n.v.); Mount Kaindi, mossy forest, 2400 m, 15 Nov 1979, Tagawa, H. 0472 (LAE); Mount Kaindi, summit, 2350 m, 8 May 1981, Reeve, T.M. 3668 (LAE, K, NSW n.v.); Mount Kaindi, upper montane forest, 2350 m, 11 Nov 1984, Cruttwell, N. 2718 (LAE); Mount Kaindi, on summit, 10 Jan 2012, Simonsson Juhonewe, N. \& Juhonewe, F. NS0019H (LAE, SING) (living accession NS12-042); Mount Kaindi, on summit, 10 Jan 2012, Simonsson Juhonewe, $N$ \& Juhonewe, F. NS0020H (LAE, SING) (living accession NS12-045); Enga Province: Mount Pimbilyo, near Laiagam, primary Nothofagus forest, 2600 m, 20 Nov 1981, Tari, J. \& Reeve, T.M. 4352 (LAE, K, NSW n.v.); Oro Province: Kokoda Track, Alola, c. 6000 ft [c. 1830 m], Dec 1935, Carr, C.E. s.n. (SING [SING0121847]); Central Province: Kokoda Track, The Gap, c. 7000 ft [c. 2135 m], 9 Dec 1935, Carr, C.E. 13714 (SING [SING0121849, SING0121850, SING0121851, SING121852]), Kokoda Track, Above The Gap, c. 8000 ft [c. 2440 m], 2 Jan 1936, Carr, C.E. s.n. (SING [SING0121848]).

Notes. Hoya krusenstierniana may be easily confused with the more common and widespread Hoya solaniflora which thrives at lower elevations of 1200-1800 m. Both sterile specimens and dry flowers of the two species can be easily confused as both species have variable leaf shape and thickness. In the living state Hoya krusenstierniana is easily distinguished by its purple to rich crimson flowers and by its scent, which is reminiscent of peeled unripe green bananas, whereas $H$. solaniflora has pale flowers in shades of white- yellow-pink and with a scent more similar to Gardenia jasminoides J.Ellis. Usually the corona is a key character for species delimitation in Hoya as it is very stable but obviously not for this taxon. The corona morphology of Hoya krusenstierniana is quite variable within the population on Mt. Kaindi (Fig. 16, 17) and is therefore not a good morphological character to distinguish the species. Instead, it is the intense crimson colouring (rarely pale pink) and the unusual flower scent that suggests a different pollinator than that of the similar Hoya solaniflora.

Hoya koteka Simonsson \& Rodda, sp. nov.

Similar to Hoya multiflora Blume in its conical buds with five basal humps in line with the corolla lobe sinuses. However, Hoya koteka has single-flowered inflorescences while $H$. multiflora has inflorescences with numerous flowers. - TYPE: Indonesia, Papua Province, Geitenkamp, 12 July 1907, Versteeg, G. 1431 (holotype L [L0794363]; isotypes A, BO, L [L0794364]). (Fig. 18) 
Climber or spreading lax shrub or climber; presence of latex unknown. Stems cylindrical, 1.5-4 $\mathrm{mm}$ in diameter, hirsute, older stems leafless, glabrous; internodes 2-5 cm long. Leaves petiolate; petiole terete, channelled above, $3-5 \times$ c. $1 \mathrm{~mm}$ in diameter, sparsely hirsute below, lamina narrowly elliptic, coriaceous when dry, $(5-) 7-10 \times 1.7-3.5 \mathrm{~cm}$, puberulous on the abaxial surface, adaxial surface glabrous, older leaves glabrous, apex caudate, base acute; venation pinnate, midrib depressed on adaxial surface, raised on adaxial surface, secondary veins 4-7 each side, anastomosing near the leaf margin, branching from the midrib at c. $60^{\circ}$; leaf colleters not present on dry specimens. Inflorescences single-flowered, peduncle extra axillary, perennial, terete, $1.5-3 \mathrm{~mm} \times$ c. $1 \mathrm{~mm}$, older peduncles bearing overlapping scars from previous flowerings forming a short rachis, glabrous or sparsely pubescent; pedicels terete, $1.5-2 \mathrm{~cm} \times$ c. $0.5 \mathrm{~mm}$ in diameter, glabrous. Flower buds conical, with five basal humps in line with the corolla lobe sinuses. Calyx c. $2 \mathrm{~mm}$ in diameter, calyx lobes triangular, c. $0.5 \times 1 \mathrm{~mm}$, apex acute, glabrous with basal lanceolate colleters, c. $50 \mu \mathrm{m}$ long. Corolla probably spreading (not possible to verify on herbarium material alone), $1.5-2 \mathrm{~cm}$ in diameter, tube $2-2.5 \mathrm{~mm}$, lobes narrowly lanceolate, $0.7-10 \times 2.5-3 \mathrm{~mm}$, pubescent inside, glabrous outside, apex acuminate. Corona staminal, stipitate, stipe elongated conical-truncate, c. $2 \mathrm{~mm}$ high, c. $1 \mathrm{~mm}$ wide at base, tapering to c. $0.6 \mathrm{~mm}$ at apex; corona c. $2.5 \mathrm{~mm}$ high, c. $2.7 \mathrm{~mm}$ in diameter, fleshy; corona lobes carinate, the inner half attached at the back of the anthers, the outer half free, c. $2 \times 0.5 \mathrm{~mm}$, inner processes acute, slightly bilobed at the tip, outer processes truncate, lacking basal revolute margins. Style-head linear with round apex extending above the corona lobes and anther appendages, 2-3 mm long. Pollinia ovoid, c. $250 \times 180 \mu \mathrm{m}$, without sterile edge, corpusculum ovoid, c. $120 \times 70 \mu \mathrm{m}$, caudicles attached at the base of corpusculum, thin and narrow, c. $100 \times 15 \mu \mathrm{m}$. Ovary linear, 1.5-2 mm long, glabrous. Fruits linear, 15-20 cm long.

Distribution. Recorded from a single locality in Papua Province, Indonesia.

Etymology. Named after its elongated style-head that resembles the traditional koteka, or penis-gourd traditionally worn by male natives of New Guinea.

Habitat and ecology. Unknown.

Provisional IUCN conservation assessment. Data deficient (IUCN, 2016) as it is known only from the type specimen collected 110 years ago.

Notes. Hoya koteka is similar to Hoya multiflora Blume in the vegetative morphology, as it appears to be a non-climbing epiphyte with thin leaves and lacks basal lamina colleters. The general flower morphology is also rather similar as the corolla has lanceolate lobes and the corona is stalked with elongated corona lobes. The flowers, however, are much smaller in Hoya koteka (corona c. $2.5 \mathrm{~mm}$ high, c. $2.7 \mathrm{~mm}$ in diameter in Hoya koteka vs. $>5 \mathrm{~mm}$ high and $>7 \mathrm{~mm}$ in diameter in H. multiflora) and 


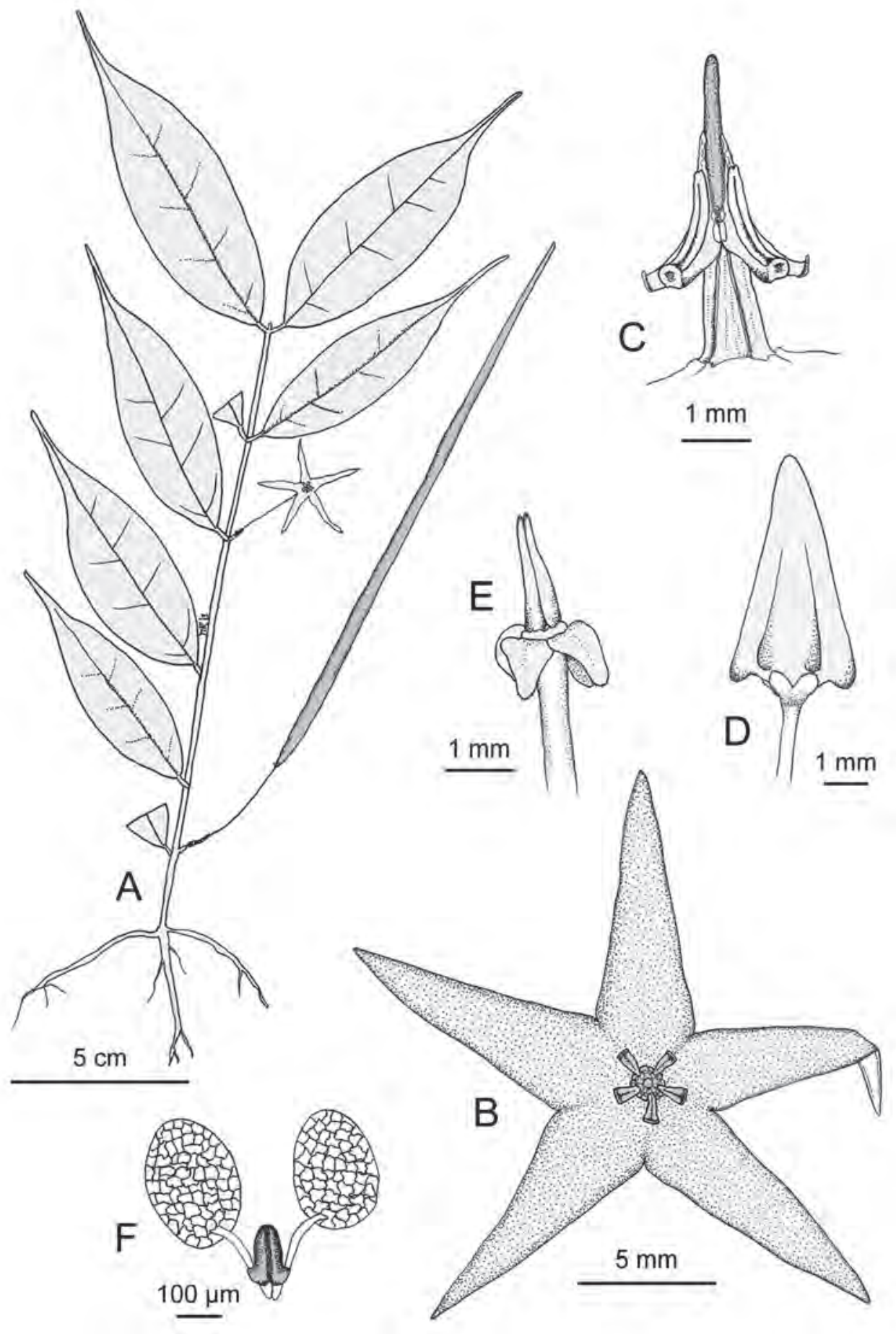

Fig. 18. Hoya koteka Simonsson \& Rodda. A. Whole plant. B. Flower, top view. C. Corona, side view. D. Bud, E. Calyx and ovaries. F. Pollinarium. All based on Versteeg, G. 1431. (Drawing: M. Rodda) 
the pollinia do not have a sterile edge, as has also been observed in Hoya juhoneweana and Hoya urniflora but otherwise present in most other Hoya species. Notable exceptions are also the species in Hoya section Eriostemma and the species formerly included in the genus Clemensiella.

Hoya stenakei Simonsson \& Rodda, sp. nov.

Similar to Hoya onychoides P.I.Forst., Liddle \& I.M.Liddle in flower size and clawed corolla but differs from it by the almost pentagonal corona and densely pubescent corolla whereas $H$. onychoides has a narrowly star-shaped corona and glabrous corolla. - TYPE: Papua New Guinea, Sandaun Province, Baiberi, 1 March 2011, lowland rainforest. Simonsson Juhonewe, N., \& Juhonewe, F. NS0026H (holotype LAE; isotype SING). (Fig. 19, 20)

Vigorous epiphytic climber with white latex in all vegetative parts. Stems cylindrical, 3-10 $\mathrm{mm}$ in diameter, dark green, new growth often slightly pubescent, later glabrous; older stems leafless and lignified, up to $15 \mathrm{~mm}$ in diameter, greyish-brown, glabrous with peeling bark; internodes 3-30 cm long. Leaves pendulous, petiolate; petiole terete, $20-50 \times$ c. $4-8 \mathrm{~mm}$ in diameter, green to brown, glabrous (sparsely pubescent when young); lamina lanceolate, very succulent and fleshy, 10-30 × 5-12 cm, dark green on adaxial surface, light green on abaxial surface, glabrous, apex acute, base cordate; pinnate, midrib depressed on adaxial surface, secondary veins 4-7 each side, secondary veins sometimes protruding, anastomosing in the middle between midrib and leaf margin, branching from the midrib at $45-80^{\circ}$. Inflorescences one per node, extra-axillary, positively geotropic, pseudo-umbelliform, convex, consisting of 2-10 flowers; peduncle terete, $2-7 \mathrm{~cm} \times 2-5 \mathrm{~mm}$, older peduncles forming a rachis from previous flowerings. Flowers scented like Gardenia jasminoides, especially at night. Corolla spreading, c. $7 \mathrm{~cm}$ when flattened, pastel pink with $2-3 \mathrm{~cm}$ wide pale cream yellow centre inside, outside cream; tube c. $1.5 \mathrm{~cm}$ long, inside pubescent, outside glabrous, lobes fleshy, triangular-acuminate, c. $3 \times 2 \mathrm{~cm}$, inside thickly pubescent, denser along margin and on apices, outside glabrous, margin c. $5 \mathrm{~mm}$ reflexed to revolute, apex acute. Corona staminal c. $1 \mathrm{~cm}$ high, $2 \mathrm{~cm}$ in diameter, fleshy, cream coloured; lobes rhomboid, centrally ridged and laterally grooved, c. $1 \times 0.7 \mathrm{~cm}$, inner processes cuspidate, meeting in centre, outer processes laterally compressed, c. $0.8 \mathrm{~cm}$ lower than inner processes, basal margins spreading, touching only towards the apex of the outer corona lobe. Style-head convex, hidden by anther appendages, which in turn are partially covered by the overlapping inner coronal processes. Pollinia linear, 1.9-2.1 mm $\times 450-550 \mu \mathrm{m}$, lacking sterile edge, corpusculum 550-650 $\times 400-450$ $\mu \mathrm{m}$, caudicles attached at the middle of corpusculum, 250-300 × c. $150 \mu \mathrm{m}$. Ovary conical, c. $8 \mathrm{~mm}$ long, glabrous. Fruits and seeds not observed. 


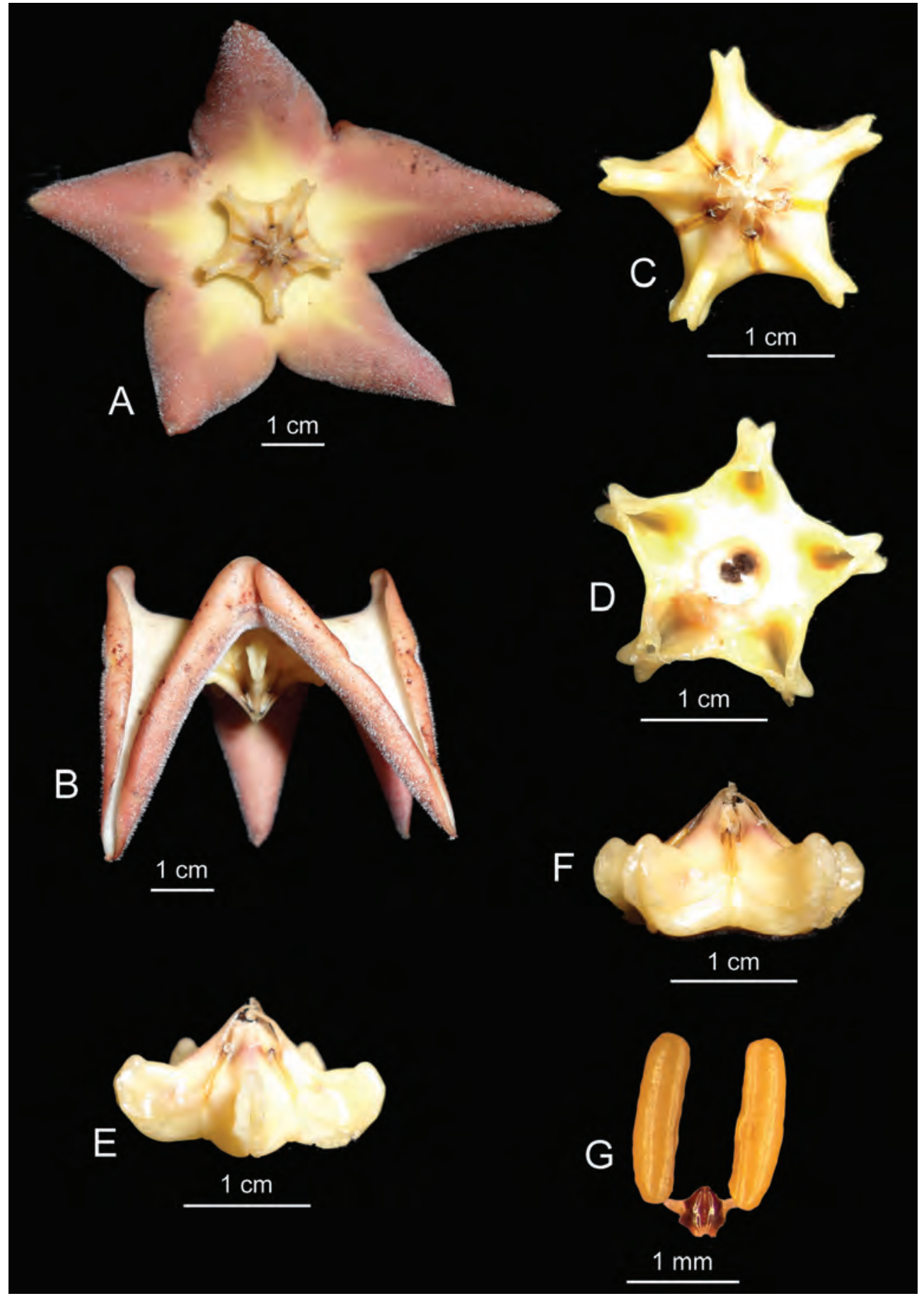

Fig. 19. Hoya stenakei Simonsson \& Rodda. A. Flower, top view. B. Flower, side view. C. Corona, top view. D. Corona, from underneath. E, F. Corona, side view. G. Pollinarium. All from Simonsson Juhonewe, N., \& Juhonewe, F. NS0026H. (Photos A-F: N. Simonsson Juhonewe; G: M. Rodda) 

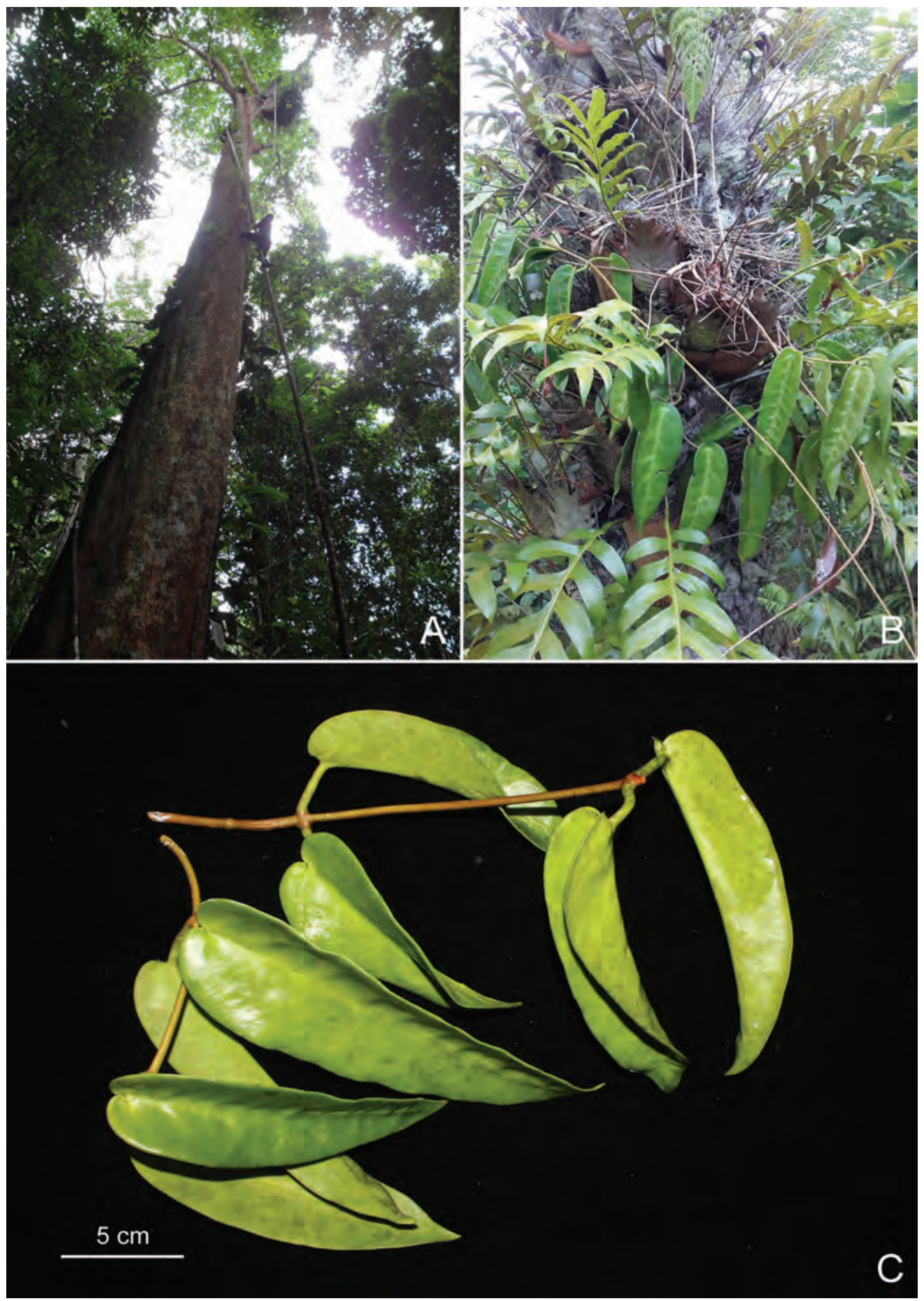

Fig. 20. Hoya stenakei Simonsson \& Rodda. A. The plant was found growing at the top of a large tree. A climber managed to reach the top of the tree and collect some material. B. The plant in cultivation. C. The large, shiny leaves. (Photos: N. Simonsson Juhonewe) 
Distribution. Known only from the type locality in Sandaun Province, Baiberi.

Etymology. Named after the late Mr Sten-Åke Svensson (1947 - 2011) of Sweden, whose children supported the first author's work in PNG.

Habitat and ecology. The single known specimen was growing as an epiphyte 20 metres up in a very tall tree, nestling inside a fern, Asplenium sp., in a species-rich primary forest with limestone karsts.

Provisional IUCN conservation assessment. Critically Endangered CR B2ab(ii,iii), C1, C2(ai), D (IUCN, 2016). Several botanical expeditions have been conducted in the vicinity of the type locality, both by the first author and several other earlier botanists, but Hoya stenakei was found only once. The two similar species Hoya archboldiana C.Norman and Hoya onychoides P.I.Forst., Liddle \& I.M.Liddle, on the other hand, were encountered several times during the first author's expeditions in PNG. The type locality was to be logged soon after our expedition and it must now be assumed that this locality is destroyed.

Notes. A new species with one of the largest flowers in the entire genus. It belongs to the Hoya macgillivrayi group, up until now consisting of only three species, $H$. macgillivrayi F.M.Bailey from Cape York in Queensland, Australia, and two from Papua New Guinea, H. archboldiana and $H$. onychoides. The new taxon is the most distinct of these species as their coronas are narrowly star-shaped, when viewed from above, and the inside of their corolla lobes are glabrous, whereas Hoya stenakei has an almost pentagonal corona and the inside of the corolla lobes is densely pubescent.

Key to species in the Hoya macgillivrayi group

(modified from Forster et al., 1995):

1a. Inside of corolla lobes pubescent; corona almost pentagonal H. stenakei

1b. Inside of corolla lobes glabrous; corona narrowly star-shaped 2

2a. Corolla campanulate, lobes shorter than the tube and $<15 \mathrm{~mm}$ long, reflexed ......... H. archboldiana

2b. Corolla campanulate-rotate or rotate, lobes as long as or longer than the tube and $>15 \mathrm{~mm}$ long, semi-erect to incurved 3

3a. Corolla lobes strongly incurved giving a 'claw-like' appearance to the lobe, with margins strongly reflexed creating a protrusion at the base of sinus between the corolla lobes H. onychoides

3b. Corolla lobes weakly incurved, with margins slightly reflexed with no protrusion formed at the base of the sinus between the corolla lobes Hoya macgillivrayi 
Hoya urniflora (P.I.Forst) Simonsson \& Rodda, comb. nov. - Marsdenia urniflora P.I.Forst., Austral. Syst. Bot. 8: 752 (1995). - TYPE: Papua New Guinea, Oro Province, Lala River, c. 5500 ft. [c. 1675 m], 28 December 1935, Carr, C.E. 14065 (lectotype SING [SING0122003], designated here; isolectotypes BM [BM001014154], K, L, SING [SING122001, SING122002]). (Fig. 12, 21, 22).

Similar to Hoya juhoneweana because both have sunken leaf venation and a bullate leaf surface. Hoya juhoneweana has corollas $>2.5 \mathrm{~cm}$ wide whereas H. urniflora have corollas c. $1.5 \mathrm{~cm}$ wide.

Epiphytic climber with white exudate latex in all vegetative parts. Stems cylindrical, 1.5-3 $\mathrm{mm}$ in diameter, sparsely to densely hispid; internodes $3-25 \mathrm{~cm}$ long. Leaves petiolate; petiole terete, $4-8 \times 1-2 \mathrm{~mm}$ in diameter, hirsute; lamina lanceolate, stiff and chartaceous, (1.5-)3-10 × 1-2.5 cm, hirsute on the abaxial surface, adaxial surface very hispid when young, almost glabrous on old leaves, apex long acuminate, base attenuate to acute with single, ovoid basal colleters; venation pinnate, midrib and secondary veins depressed on adaxial surface, raised on abaxial surface, secondary veins slightly visible, $2-5$ each side, branching from the midrib at $45-80^{\circ}$, anastomosing along the lamina edge. Inflorescences one per node, extra-axillary, convex, consisting of (1-)510 widely spaced flowers, peduncle perennial, terete, $0.4-2(-3) \mathrm{cm} \times 1.5-2 \mathrm{~mm}$, older peduncles forming a rachis from previous flowerings, hirsute; pedicels terete, 1.5-2 $\mathrm{cm} \times$ c. $1 \mathrm{~mm}$ in diameter, hirsute. Calyx 3-4 $\mathrm{mm}$ in diameter, calyx lobes oblong, $1-2 \times 1-1.5 \mathrm{~mm}$, apex round, thinly pubescent outside; colleters one in each calyx lobe sinus, c. $50 \mu \mathrm{m}$ long. Corolla base narrowly campanulate, terminating in free spreading lobes, 14-16 mm wide; tube 5-6 × 5-6 mm, sparsely pubescent inside, more thickly pubescent at the throat, outside glabrous, lobes triangular, 5-9 $\times 3.5-4.5 \mathrm{~mm}$, velvety, outside glabrous, apex acute. Corona staminal 4.5-5.5 mm high, 4.5-5.5 mm wide, fleshy; corona lobes erect, almost completely fused to the back of the anthers, c. $4 \times 1.5-2 \mathrm{~mm}$, inner processes acute with a round tip, outer processes round, with basal revolute margins. Style-head conical, hidden by anther appendages. Pollinia oblong 400-500 × 150-200 $\mu \mathrm{m}$, without sterile edge, corpusculum ovoid, 350-400 $\times$ 230-300 $\mu \mathrm{m}$, caudicles attached at the base of the corpusculum, 130-170 $\times$ c. $50 \mu \mathrm{m}$. Ovary conical, c. $2 \mathrm{~mm}$ long. Fruits and seeds not observed.

Distribution. First collected by Carr in 1935 (Carr 14065) along the Kokoda Track over the Owen Stanley Range along the border of Central and Oro Provinces, where he also collected Hoya carrii. In 1970 a specimen (Streimann \& Kairo NGF42473) was collected $260 \mathrm{~km}$ NW in southern Morobe province on the Central Range. The species was collected again in 2011 at the easternmost end of the Finisterre Range on Huon Peninsula, $290 \mathrm{~km} \mathrm{~N}$ of the first collection and $190 \mathrm{~km} \mathrm{NE}$ of the second collection (N. S. Juhonewe \& F. Juhonewe NS0069L, NS0096L, NS0098L, NS0099L, NS0100L, NS0101L, NS0102L). This suggests a widespread distribution, although the taxon may still be rare and very scattered since it has only been encountered at one locality during the first author's expeditions. 

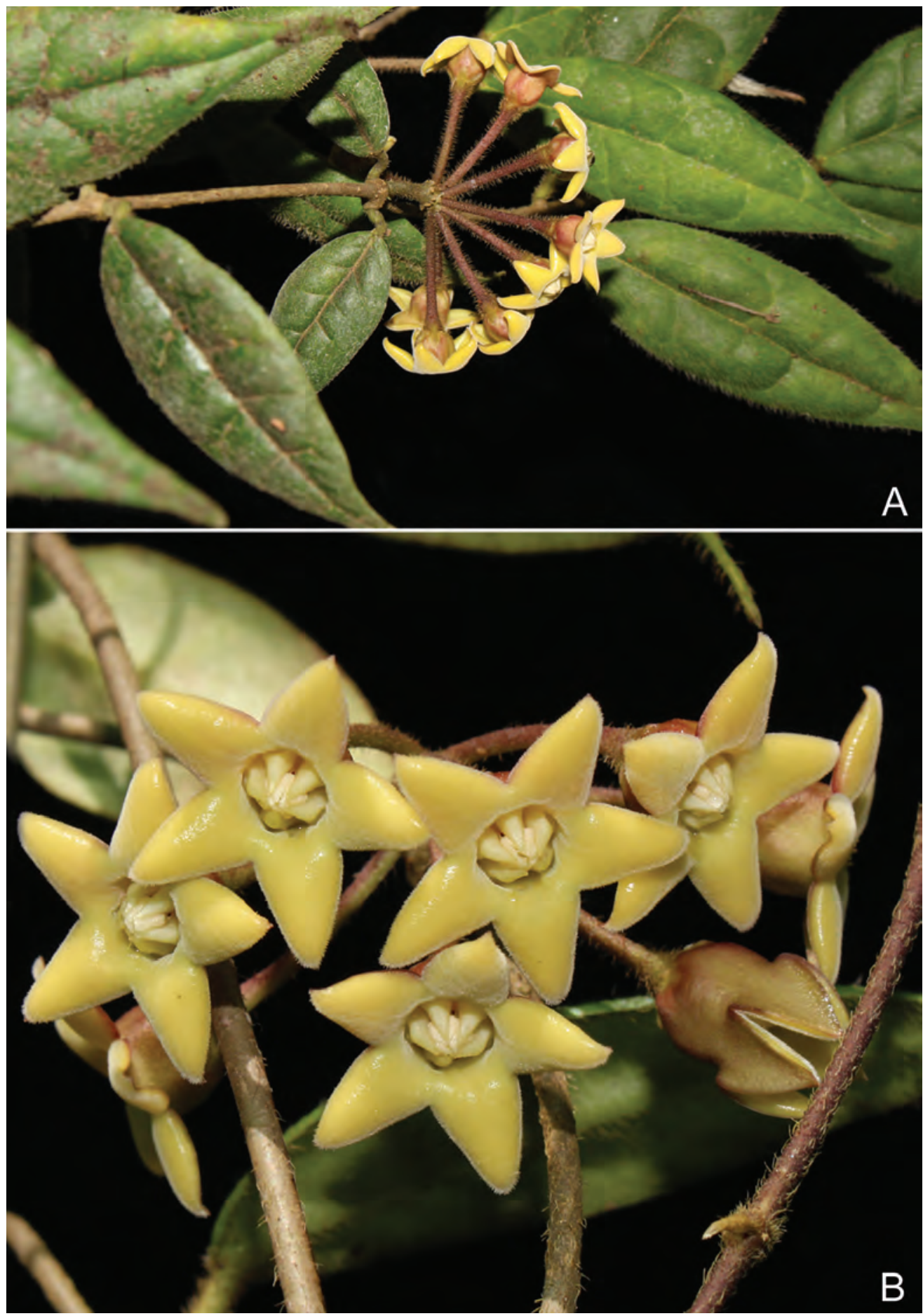

Fig. 21. Hoya urniflora (P.I.Forst.) Simonsson \& Rodda inflorescence A. Side view. B. From underneath. All from Simonsson Juhonewe, N. \& Juhonewe, F. NS0098L. (Photos: F. Juhonewe) 


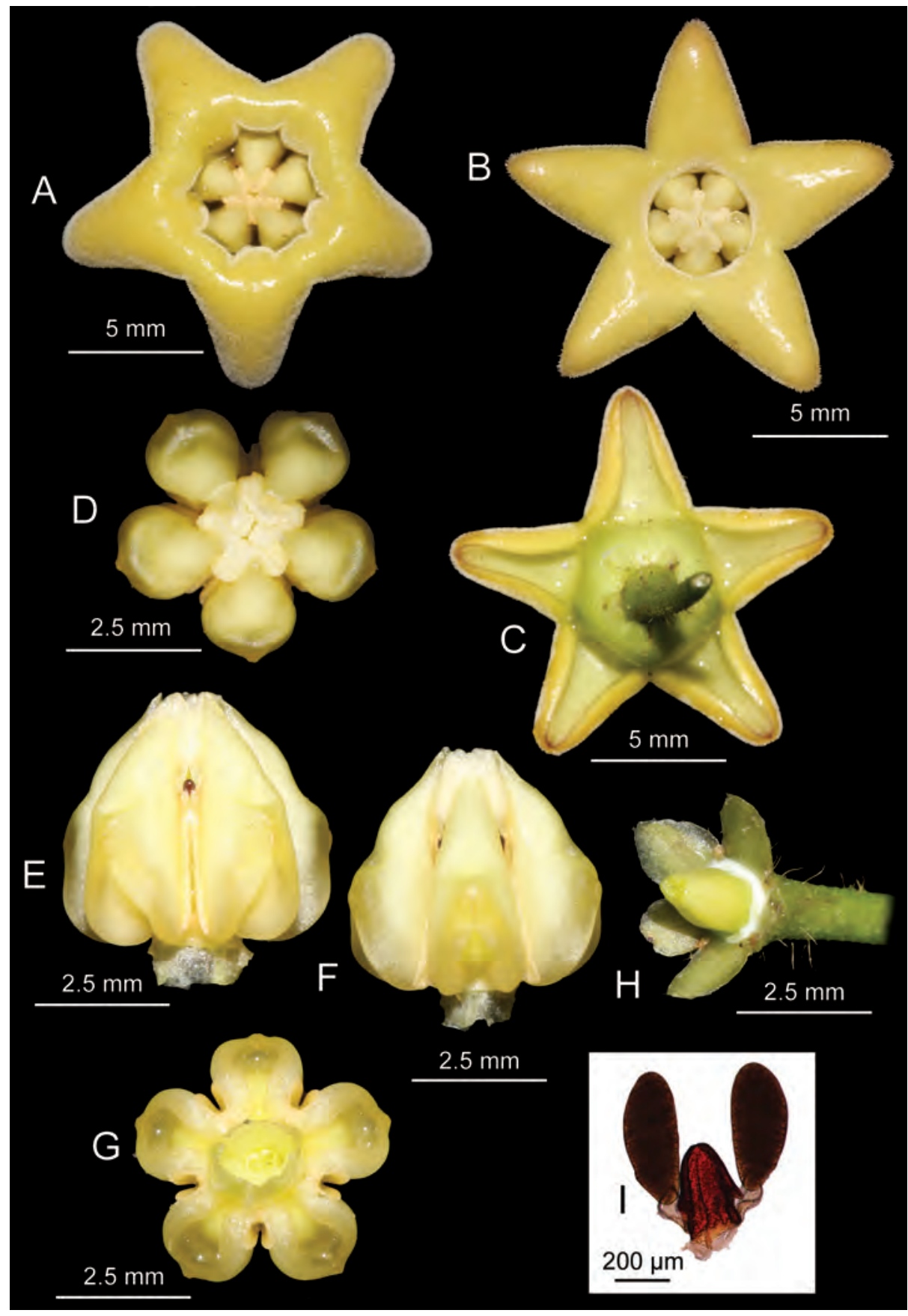

Fig. 22. Hoya urniflora (P.I.Forst.) Simonsson \& Rodda. A, B. Corolla from above. C. Corolla and calyx, from underneath. D. Corona from above. E, F. Corona, side view. G. Corona from underneath. H. Calyx and ovaries. I. Pollinarium. A from Simonsson Juhonewe, N. \& Juhonewe, F. NS0098L, C-I from Simonsson Juhonewe, N. \& Juhonewe, F. NS0102L. (Photos A-H: F. Juhonewe; I: M. Rodda) 
Habitat and ecology. It inhabits primary moist cloud forest at 1800-2000 m. It climbs until it finds support on branches and then sends out stiff spreading branches which flower several times a year. In cultivation it proved to be quite sensitive to both warm and dry conditions and was rather difficult to propagate and transplant, with several failed attempts. This is, therefore, a very sensitive species and is likely to suffer under human pressure and global warming.

Provisional IUCN conservation assessment. Endangered B2a,b(iii) (IUCN, 2016). Hoya urniflora is a locally rare but widespread species that is very susceptible to forest degradation.

Additional specimens examined. PAPUA NEW GUINEA: Morobe Province: Menyamya district, Spreader Divide, between Aseki and Menyamya, $6600 \mathrm{ft}$ [c. $2010 \mathrm{~m}$ ], epiphyte climbing over small vegetation, $7^{\circ} 18^{\prime} \mathrm{S} 146^{\circ} 07^{\prime} \mathrm{E}, 21$ Nov 1970, Streimann \& Kairo NGF 42473 (LAE); Huon Peninsula, Hoboc, 1850 m, 24 Dec 2011, living accession NS11-321, vouchered at Ukarumpa on 31 May 2013, Simonsson Juhonewe, N. \& Juhonewe, F. NS0069L (LAE, SING); Huon Peninsula, Hoboc, 1900 m, 24 Dec 2011, living accession NS11-327, vouchered at Ukarumpa on 9 Mar 2014, Simonsson Juhonewe, N. \& Juhonewe, F. NS0096L (LAE); Huon Peninsula, Hoboc, 1850 m, 24 Dec 2011, living accession NS11-322, vouchered at Ukarumpa on 28 Aug 2014, Simonsson Juhonewe, N. \& Juhonewe, F. NS0098L (LAE); Huon Peninsula, Hoboc, 1850 m, 24 Dec 2011, living accession NS11-323, vouchered at Ukarumpa on 9 Jun 2014, Simonsson Juhonewe, N. \& Juhonewe, F. NS0099L (LAE); Huon Peninsula, Hoboc, 1900 m, 24 Dec 2011, living accession NS11-326, vouchered at Ukarumpa on 31 Dec 2014, Simonsson Juhonewe, N. \& Juhonewe, F. NS0100L (LAE); Huon Peninsula, Hoboc, 2013 m, 29 Dec 2011, living accession NS11-349, vouchered at Ukarumpa on 31 Jan 2016, Simonsson Juhonewe, N. \& Juhonewe, F. NS0101L (LAE); Huon Peninsula, Hoboc, 1885 m, 29 Dec 2011, living accession NS11-354, vouchered at Ukarumpa on 29 Sep 2014, Simonsson Juhonewe, $N$. \& Juhonewe, F. NS0102L (LAE).

Notes. Hoya urniflora was described as Marsdenia urniflora P.I.Forst. (Forster 1995: 752) with a holotype in SING. However, there are three duplicates of Carr 14065 in SING with none of them labelled as the holotype. Following ICN Art. $8.1 \& 8.2$ (McNeill et al., 2012) a holotype may only be a single specimen. Therefore, we select a lectotype here, specimen SING0122003.

The taxon should be placed in Hoya because, despite lacking the sterile edge of the pollinia typical of Hoya, it does have valvate bud aestivation, a character difficult or impossible to observe on dry specimens with only open flowers but easily seen in fresh material. Bud aestivation in Marsdenia R.Br. is instead imbricate. Pollinia without a sterile edge in Hoya are not limited to H. urniflora but typical of species in Hoya section Eriostemma and, in Papuasia, is also lacking in Hoya juhoneweana.

Hoya urniflora is easily distinguished from the majority of Hoya species due to the conspicuous sunken venation causing a characteristic bullate leaf surface, and by its dense cover of $>1 \mathrm{~mm}$ long hairs on all vegetative parts, especially when young. Vegetatively it can only be confused with the new taxon Hoya juhoneweana Simonsson \& Rodda. However, Hoya juhoneweana has pendulous stems while H. urniflora 
develops climbing stems. When in flower, the two taxa are easily distinguished, as Hoya juhoneweana has corollas $>2.5 \mathrm{~cm}$ wide whereas the corollas of $H$. urniflora are c. $1.5 \mathrm{~cm}$ wide (Fig. 12).

\section{Hoya versteegii Simonsson \& Rodda, sp. nov.}

Similar to numerous other Hoya species with elliptic and succulent leaves but differing from all other Hoya species in the infundibuliform corolla with a continuously narrow tube. - TYPE: Indonesia, Papua Province, Voer Gelukshauvel, s. dat., Versteeg, G. 1236 (holotype BO). (Fig. 23)

Climber, presence of latex unknown. Stems cylindrical, 1.5-4 $\mathrm{mm}$ in diameter, sparsely pubescent; internodes $4-15 \mathrm{~cm}$ long. Leaves petiolate; petiole terete, channelled above, $10-15 \times 3-5 \mathrm{~mm}$ in diameter, pubescent; lamina elliptic, fleshy, stiff and coriaceous when dry, 8-15 × 3-6 cm, pubescent on the abaxial surface, adaxial surface glabrous to sparsely pubescent, apex acuminate-apiculate, base round with no colleters on old leaves; venation pinnate, midrib depressed on adaxial surface, raised on adaxial surface, secondary veins almost invisible, 3-5 each side, branching from the midrib at c. $45^{\circ}$. Inflorescences one per node, extra-axillary, convex, consisting of 3 or more flowers, peduncle perennial, terete, $5-10 \mathrm{~cm} \times 1.5-2 \mathrm{~mm}$, older peduncles forming a rachis, glabrous or sparsely pubescent; pedicels terete, $2.5-3 \mathrm{~cm} \times$ c. 0.8 $\mathrm{mm}$ in diameter, glabrous. Calyx $3-3.5 \mathrm{~mm}$ in diameter, calyx lobes oblong, $1-2 \times$ $0.7-1 \mathrm{~mm}$, apex round, thinly pubescent outside, basal colleters one in each calyx lobe sinus, lanceolate, c. $50 \mu \mathrm{m}$ long. Corolla infundibuliform, with free spreading lobes, c. $2.5 \mathrm{~cm}$ in diameter when flattened; tube $12-15 \mathrm{~mm} \times$ c. $3 \mathrm{~mm}$, sparsely pubescent inside, more densely pubescent at throat, lobes broadly ovate, $7-10 \times 9-12$, apex acuminate, glabrous. Corona staminal, stipitate, stipe 1-1.5 mm high, c. 1.5 $\mathrm{mm}$ wide; corona c. $3 \mathrm{~mm}$ high, c. $3 \mathrm{~mm}$ in diameter, fleshy; corona lobes carinate, almost completely fused to the back of the anthers, c. $3 \times 1 \mathrm{~mm}$, inner processes acute with a round tip, outer processes round, with basal revolute margins. Style-head hidden by anther appendages. Pollinia oblong, 500-600 × 280-320 $\mu \mathrm{m}$ with pellucid margin, corpusculum rhomboid, c. $400 \times 250 \mu \mathrm{m}$, caudicles attached at the base of corpusculum, 100-150 × 30-40 $\mathrm{m}$. Ovary linear, c. $2.5 \mathrm{~mm}$ long, glabrous. Fruits and seeds not observed.

Distribution. Recorded from a single locality in Papua Province, Indonesia, Voer Gelukshauvel.

Etymology. Named after its collector, G. Versteeg (1876-1943).

Provisional IUCN conservation assessment. Data Deficient (IUCN, 2016). This species is known only from the type specimen collected in the early 20th century. 

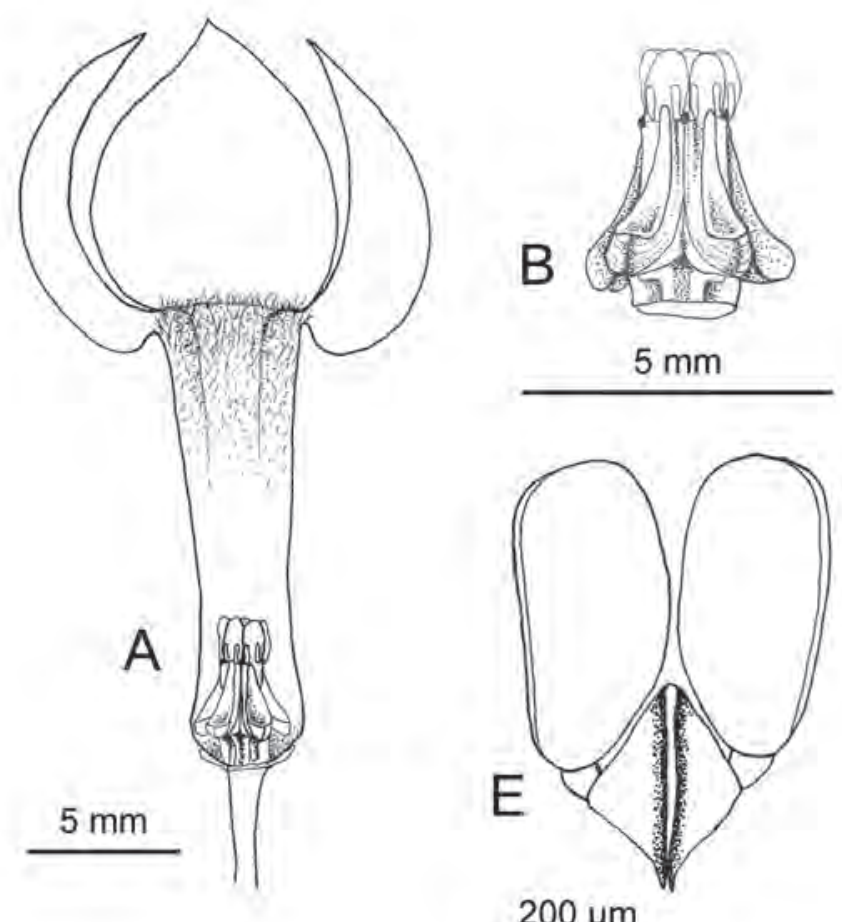

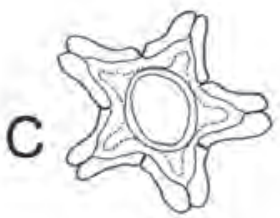

$5 \mathrm{~mm}$

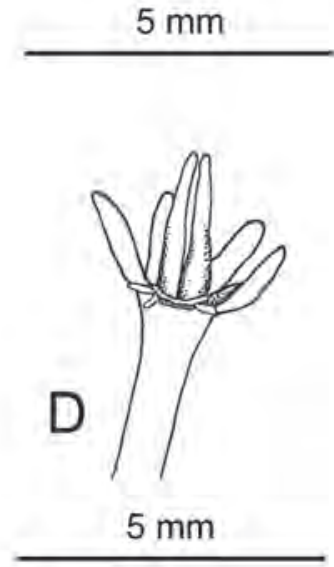

Fig. 23. Hoya versteegii Simonsson \& Rodda. A. Corolla sliced longitudinally showing the position of the corona. B. Corona, side view. C. Corona, from underneath. D. Calyx and ovaries. E. Pollinarium. All based on Versteeg, G. 1236. (Drawing: M. Rodda)

Notes. The flowers of Hoya versteegii, with their infundibuliform corolla and a long narrow tube, may at first be confused with those of other genera, e.g. Marsdenia s.l. The gynostegium is instead typical of Hoya as the corona lobes have revolute margins, albeit much reduced, and the pollinia have a narrow sterile edge. Among other Hoya species, only $H$. telosmoides Omlor from Borneo and $H$. papaschonii Rodda from Thailand have a tubular corolla, but in both cases they are not continuously narrow as in $H$. versteegii. Additionally the corolla tube of Hoya versteegii is $12-15 \mathrm{~mm}$ long white that of $H$. telosmoides and $H$. papaschonii is less than $10 \mathrm{~mm}$ long. Both species have much thinner leaves, chartaceous when dry, while Hoya versteegii has stiff and coriaceous leaves.

Hoya yvesrocheri Simonsson \& Rodda, sp. nov.

Similar to Hoya stenophylla Schltr. by having linear leaves but differs in the wider leaves and flowers not developing simultaneously, as usually observed in most Hoya species, but rather with only one or rarely two flowers open at a time. - TYPE: Papua 
New Guinea, Morobe Province, Wagau, $4200 \mathrm{ft}$ [c. $1280 \mathrm{~m}$ ], found in large tree in old garden near village, $6^{\circ} 50^{\prime} \mathrm{S} 146^{\circ} 50^{\prime} \mathrm{E}, 11$ June 1964, Millar, A.N. NGF 23466 (holotype LAE; isotypes L [L2726759], CANB n.v.). (Fig. 24)

Liana slender, glabrous with white latex in vegetative parts. Leafy stems cylindrical, 1-2 $\mathrm{mm}$ in diam; older stems lignified, max diameter (up to 3-4 $\mathrm{mm}$ in diameter), colour greenish brown, bark peeling; internodes 1-5(10) cm long. Leaves usually hanging, petiolate; petiole terete, c. $2-5 \times 1-1.5 \mathrm{~mm}$ in diameter, green without markings; lamina linear or slightly lanceolate, coriaceous, carinate, c. 5-10 $\times 0.5-1 \mathrm{~cm}$, green on both surfaces, apex acute base rounded or attenuate, margin entire; venation pinnate but barely evident in living material, midrib depressed on adaxial surface, secondary veins 4-6 each side, secondary veins anastomosing near leaf margin, branching from the midrib at c. $60-90^{\circ}$; leaf colleters 1 or 2, conical $0.3-0.4 \mathrm{~mm}$ long. Inflorescences one per node, extra-axillary, positively geotropic, pseudo-umbellate, usually 1-8 buds at different stages with only one or rarely two flower open at a time; peduncle terete, $c$. $0.5-3 \times 0.1-0.15 \mathrm{~cm}$, older peduncles bearing scars from previous flowerings, pedicels terete, $2 \mathrm{~cm} \times 0.5-1 \mathrm{~mm}$, green. Calyx c. $3 \mathrm{~mm}$ in diameter, lobes triangular-ovate, c. 0.5 $\times 0.5 \mathrm{~mm}$, glabrous. Corolla campanulate, c. $1.5 \mathrm{~cm}$ diameter (c. $2 \mathrm{~cm}$ when flattened), white with a slight pink or purple hue, intensifying with more sunlight; tube c. $7 \mathrm{~mm}$, lobes triangular, acuminate, c. $6 \times 7 \mathrm{~mm}$, margins entire, apex slightly revolute, densely pubescent with unicellular hairs, abaxially glabrous. Corona staminal c. $2 \mathrm{~mm}$ high, 5 $\mathrm{mm}$ in diameter, fleshy, creamy white-yellow with dark reddish centre; corona lobes elliptic-ovate, c. $2 \times 1 \mathrm{~mm}$, inner processes slightly erect, outer processes rounded and erect, with basal revolute margins. Style-head hidden by anther appendages. Pollinia oblong, c. $350 \times 130-150 \mu \mathrm{m}$, with sterile edge, corpusculum 150-200 × 100-110 $\mu \mathrm{m}$, caudicles attached to middle of corpusculum, c. $70 \times 30 \mu \mathrm{m}$. Ovary conical, c. $0.8 \mathrm{~mm}$ long, glabrous. Fruits and seeds unknown.

Distribution. Recorded from Morobe Province only, at altitudes between 720 and $1260 \mathrm{~m}$.

Etymology. Named after the Yves Rocher Foundation which supported the first author's Hoya Project for five years during 2011-2015.

Habitat and ecology. It seems to be confined to altitudes between 700 and 1300 metres within a small area in Morobe province. The first author has only seen it once, on a fallen tree on a very sharp ridge in primary rainforest in Bula, Morobe Province. Upon re-visiting the area in 2013 the ridge had been burned for expanding slash-and-burn subsistence gardens.

Provisional IUCN conservation assessment. Endangered EN B1ab(i,iii) (IUCN, 2016). Hoya yvesrocheri has only been found in Morobe Province between 700 and $1300 \mathrm{~m}$, an altitude where the few remnants of forest are rapidly being converted into subsistence gardens or abandoned grasslands due to the expanding population. Most 

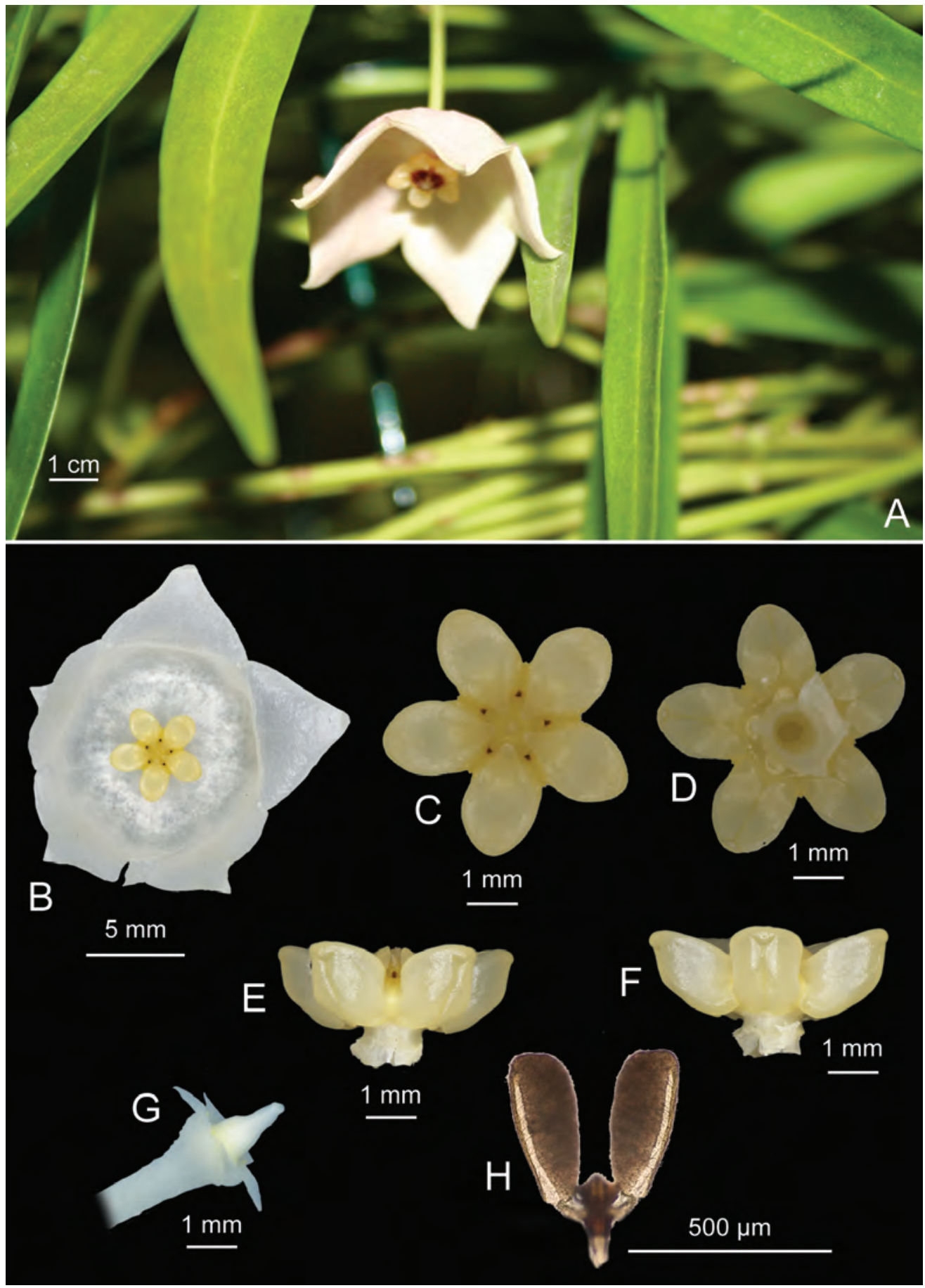

Fig. 24. Hoya yvesrocheri Simonsson \& Rodda. A. Inflorescence with a single open flower and leaves. B. Flower, top view. C. Corona, top view. D. Corona, from underneath. E, F. Corona, side view. G. Calyx and ovaries. H. Pollinarium. All from Simonsson Juhonewe, N. \& Juhonewe, F. NS0047L. (Photo A: T. Sulemana. B-H: M. Rodda) 
remaining forest in that area is above $1500 \mathrm{~m}$ and thus in a different climate zone, making it unlikely that this taxon thrives in those forests.

Additional specimens examined. PAPUA NEW GUINEA: Morobe Province: Bupu Village above Gurakor, rainforest, $2400 \mathrm{ft}[\mathrm{c} .730 \mathrm{~m}], 7^{\circ} 00^{\prime} \mathrm{S} 146^{\circ} 40^{\prime} \mathrm{E}, 27 \mathrm{Jul} 1968$, Millar, A.N. NGF 12172 (L [L2726757], LAE); Mumeng subdistrict, Bupu village, 914 m, mountain ridges, Castanopsis forest, $7^{\circ} 00^{\prime} \mathrm{S} 146^{\circ} 35^{\prime} \mathrm{E}, 15$ May 1974, Katik, P. \& Larivita, G. LAE 62031 (BRI n.v., CANB n.v., L [L2726758], LAE); Bula, 744 m, 0700'59"S 14656'44"E, 16 Feb 2008, living accession NS08-030, vouchered at Ukarumpa on 29 Jun 2012 as Simonsson Juhonewe, N. \& Juhonewe, F. NS0047L (LAE Spirit in SING).

Notes. Similar to Hoya stenophylla Schltr. in the linear leaves, a character unique to these two species in PNG. They can be easily distinguished by Hoya yvesrocheri having an evenly green colour in all vegetative parts except for older stems, leaves twice the width, and in its unique floral development where the flowers of a single inflorescence are in different stages with only one or rarely two flowers open at a time. In Hoya stenophylla all flowers develop simultaneously, the usual pattern for most Hoya species.

ACKNOWLEDGEMENTS: This study is part of an on-going research project on the systematics of Hoya. Nadhanielle Simonsson Juhonewe received support from the Yves Rocher Foundation, Helge Ax:son Johnsons Stiftelse and many individual contributors. Michele Rodda received support from the National Parks Board (Singapore), which sponsored numerous herbarium trips to Asian and European herbaria, and from the SYNTHESYS Project http://www.synthesys.info/ which is financed by the European Union under the FP7 Integrating Activities Programme, grants GB-TAF-5657, NL-TAF-676 and DE-TAF-675. We would like to thank the curators of the herbaria mentioned in the text for allowing access and/or for providing high quality images of herbarium specimens. We thank Paul Forster and the late David Liddle for their encouragement to work on Papuasian Hoya, Theresa Sulemana for the permission to use her photograph of Hoya yvesrocheri, Stephanie Pimm Lyon for the permission to use her photographs of Hoya juhoneweana ssp. juhoneweana in habitat, Foreting Juhonewe for the permission to use numerous photographs, and two anonymous reviewers for their valuable comments on the manuscript.

\section{References}

Aurigue, F.B., Sahagun, J.R. \& Suarez, W.M. (2013). Hoya cutis-porcelana (Apocynaceae): A New Species from Samar and Biliran Islands, Philippines. J. Nat. Stud. 12(1): 12-17.

Brown, G.K., Nelson, G. \& Ladiges, P.Y. (2006). Historical biogeography of Rhododendron section Vireya and the Malesian Archipelago. J. Biogeogr. 33: 1929-1944.

Forster, P.I. (1995). Circumscription of Marsdenia (Asclepiadaceae: Marsdenieae), with a revision of the genus in Australia and Papuasia. Austral. Syst. Bot. 8: 703-933.

Forster, P.I. (1996). A checklist of the Asclepiadaceae of Papuasia. Sci. New Guinea 22(1): $15-22$. 
Forster, P.I. (2006). The Asclepiad Flora of New Guinea. In: Marshall, A.J. \& Beehler, B.M. (eds) The Ecology of Papua, pt. 1, pp. 371-378. Hong Kong: Periplus Editions

Forster, P.I. \& Liddle, D.J. (1991). Variation in Hoya australis Br. ex Traill (Asclepiadaceae). Austrobaileya 3: 503-521.

Forster, P.I. \& Liddle, D.J. (1992). Taxonomic studies on the genus Hoya R.Br. (Asclepiadaceae) in Papuasia, 1-5. Austrobaileya 3: 627-641.

Forster, P.I. \& Liddle, D.J. (1993). Taxonomic studies on the genus Hoya R.Br. (Asclepiadaceae: Marsdenieae) in Papuasia, 6. Austrobaileya 4: 51-55.

Forster, P.I. \& Liddle, D.J. (1996). Hoya. In: Orchard, A.E. \& Wilson, A. (eds) Flora of Australia, vol. 28. Canberra: Australian Biological Resources Study.

Forster, P.I., Liddle, D.J. \& Liddle, I.M. (1995). Taxonomic studies on the genus Hoya R.Br. (Asclepiadaceae: Marsdenieae) in Papuasia, 7. Austrobaileya 4: 401-406.

Forster, P.I., Liddle, D.J. \& Liddle, I.M. (1997). Madangia inflata (Asclepiadaceae: Marsdenieae), a new genus and species from Papua New Guinea. Austrobaileya 5: 53-57.

Forster, P.I., Liddle, D.J. \& Liddle, I.M. (1998). Diversity in the genus Hoya (AsclepiadaceaeMarsdenieae). Aloe 35: 44-48.

Heads, M. (2006). Biogeography, ecology and tectonics in New Guinea. J. Biogeogr. 33: 957958.

Hemsley, W.A. (1891). New Solomon Islands Plants. Ann. Bot. (Oxford) 5: 501-508.

Hemsley, W.A. (1892). Decades Kewenses. Bull. Misc. Inform. Kew 65/66: 125-128.

Hemsley, W.A. (1894). Flora of the Solomon Islands. Bull. Misc. Inform. Kew 91: 211-215.

IPNI, The International Plant Names Index (2016). http://www.ipni.org. Accessed 20 Apr. 2016.

IUCN Standards and Petitions Subcommittee (2016). Guidelines for Using the IUCN Red List Categories and Criteria. Version 12. http://www.iucnredlist.org/documents/ RedListGuidelines.pdf. Accessed 16 Feb. 2017.

Kloppenburg, R.D. (1991). Philippine Hoya Species. Fresno: ORCA Publishing

Lamb, A, \& Rodda, M. (2016). A Guide to Hoyas of Borneo. Kota Kinabalu: Natural History Publications (Borneo).

Lamb, A., Gavrus, A., Emoi, B. \& Gokusing, L. (2014). The hoyas of Sabah, a commentary with seven new species and a new subspecies. Sandakania 19: 1-89.

Li, P.T., Gilbert, M.G. \& Stevens, W.D. (1995). Asclepiadaceae. In: Wu, Z.Y. \& Raven, P.H. (eds) Flora of China, vol. 16, pp. 189-270. Beijing: Science Press; and St. Louis: Missouri Botanical Garden Press.

McNeill, J., Buck, W.R., Demoulin, V., Greuter, W., Hawkworth, D.L., Herendeen, P.S., Knapp, S., Marhold, K., Prado, J., Prud'homme van Reine, W.F., Smith, G.F., Wiersema, J.H. \& Turland, N.J. (2012). International Code of Nomenclature for algae, fungi, and plants (Melbourne Code). Regnum Vegetabile, vol. 154. Königstein: Koeltz Scientific Books.

Moore, S. (1916). Asclepiadaceae. In: Ridley, H.N. Report on the Botany of the Wollaston Expedition to Dutch New Guinea, 1912-1913. Trans. Linn. Soc. London, Bot. 9: 112116.

Prance, G.T., Beentje, H., Dransfield, J. \& Johns, R. (2000). The Tropical Flora Remains Undercollected. Ann. Missouri Bot. Gard. 87: 67-71.

Rahayu, S., Meve, U. \& Rodda, M. (2015). Hoya undulata (Apocynaceae, Asclepiadoideae), a new myrmecophytic species from Borneo, and typification of H. darwinii. Gard. Bull. Singapore 67: 85-94.

Rintz, R.E. (1978). The Peninsular Malaysian species of Hoya (Asclepiadaceae). Malayan Nat. J. 30: 467-522. 
Rodda, M. (2015). Two new species of Hoya R.Br. (Apocynaceae, Asclepiadoideae) from Borneo. PhytoKeys 53: 83-93.

Rodda, M. \& Ercole, E. (2014). Hoya papaschonii (Apocynaceae: Asclepiadoideae), a new species from southern Thailand with a peculiar corona. Phytotaxa 175(2): 97-106.

Rodda, M. \& Nyhuus, T. (2009). Hoya danumensis, a new species of Hoya (Apocynaceae, Asclepiadoideae) from Borneo. Webbia 64(2): 163-167.

Rodda, M. \& Simonsson, N. (2011a). Hoya devogelii (Apocynaceae: Asclepiadoideae), a new species from Sarawak, Borneo. Webbia 66(1): 33-38.

Rodda, M. \& Simonsson, N. (2011b). Hoya medinillifolia (Apocynaceae: Asclepiadoideae), a new species from lowland forest of Sarawak, Borneo. Webbia 66(2): 149-154.

Rodda, M. \& Simonsson Juhonewe, N. (2013a). Hoya nuttiana (Apocynaceae: Asclepiadoideae), a new species from Sarawak, Malaysian Borneo. Phytotaxa 140(1): 56-60.

Rodda, M. \& Simonsson Juhonewe, N. (2013b). The taxonomy of Hoya micrantha and Hoya revoluta (Apocynaceae, Asclepiadoideae). Webbia 68: 7-16

Rodda, M., Simonsson, N. \& Wanntorp, L. (2011). Hoya wongii (Apocynaceae, Asclepiadoideae): a new campanulate flowered species from Brunei (Borneo). Blumea 56: 205-208.

Rodda, M., Simonsson Juhonewe, N. \& Ercole, E. (2014a). Hoya corymbosa (Apocynaceae: Asclepiadoideae), a new unusual species from Sabah, Borneo and its systematic position based on phylogenetic analyses. Syst. Bot. 38 (4): 1125-1131.

Rodda, M., Simonsson Juhonewe, N. \& Rahayu, S. (2014b). Taxonomic revision of the Hoya mindorensis complex (Apocynaceae:-Asclepiadoideae). Webbia 69(1): 39-47.

Rodda, M. Simonsson Juhonewe, N. \& Lamb, A. (2015). Hoya fauziana (Apocynaceae: Asclepiadoideae), a new species from Sabah, Malaysian Borneo. Webbia 70: 207-210.

Rodda, M., Lamb, A., Gokusing, L. \& Bosuang, S. (2016). Hoya jiewhoeiana (Apocynaceae, Asclepiadoideae), a new species from Sabah, Malaysian Borneo. In: Lamb, A. \& Rodda, M. A Guide to Hoyas of Borneo, pp. 198-200. Kota Kinabalu: Natural History Publications (Borneo).

Schlechter, R. (1905). Hoya. In: Schumann, K.M. \& Lauterbach, C.A.G. Nachträge zur Flora der deutschen Schutzgebiete in der Südsee mit Ausschluss Samoa's und der Karolinen, pp. 362-367. Leipzig :Gebrüder Borntraeger

Schlechter, R. (1908). Beiträge zur Kenntnis der Asclepiadaceen des Monsun-Gebietes. Bot. Jahrb. Syst. 40, Beibl. 92: 1-19.

Schlechter, R. (1913). Die Asclepiadaceen von Deutsch-Neu-Guinea. Bot. Jahrb. Syst. 50: 81-164.

Shearman, P.L., Ash, J., Mackey, B., Bryan, J.E. \& Lokes, B. (2009). Forest Conversion and Degradation in Papua New Guinea 1972-2002. Biotropica 41: 379-390.

Van Welzen, P.C. (1998). Increased speciation in New Guinea: tectonic causes? In: Dransfield, J., Coode, M.J.E. \& Simpson, D.A. (eds) Plant Diversity in Malesia III: Proceedings of the Third International Flora Malesiana Symposium 1995, pp. 363-387. Kew: Royal Botanic Gardens.

Vollering, J., Schuiteman, A., de Vogel, E., van Vugt, R. \& Raes, N. (2016). Phytogeography of New Guinean orchids: patterns of species richness and turnover. J. Biogeogr. 43: 204-214.

Wanntorp, L. \& Forster, P.I. (2007). Phylogenetic Relationships between Hoya and the Monotypic Genera Madangia, Absolmsia, and Micholitzia (Apocynaceae, Marsdenieae): Insights from Flower Morphology. Ann. Missouri Bot. Gard. 94: 36-55.

Whitmore, T.C. (1984). A vegetation map of Malesia at scale 1:5 million. J. Biogeogr. 11: 461-471. 
